\title{
THE EFFECT OF LEAKED INFORMATION ON THE RULES OF INTERNATIONAL LAW
}

\author{
WILLIAM THOMAS WORSTER*

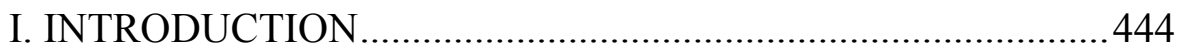 \\ II. SOURCES OF INTERNATIONAL LAW ................................446 \\ A. EX TURPI CAUSA NON ORITUR ACTIO.................................... 447 \\ B. THE LAW OF TREATIES .....................................................449 \\ 1. Definition of a Treaty ..................................................449 \\ a. Secret Treaties...................................................... 450 \\ b. Non-Legally Binding Agreements..........................451 \\ 2. Interpretation of Treaty Terms .....................................455 \\ a. Fruit of the Poisonous Tree.........................................455 \\ b. Ordinary Meaning, Context, and Object and

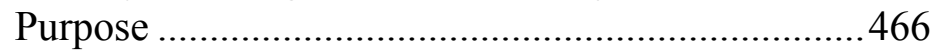 \\ c. Subsequent Practice ................................................. 468 \\ d. Travaux Prépératoires...........................................4 470 \\ C. BINDing Unilateral Statements ...................................472 \\ D. CuSTOMARY INTERNATIONAL LAW ......................................473 \\ E. ACTS OF INTERNATIONAL ORGANIZATIONS .........................481 \\ III. INTERNATIONAL LEGAL PERSONALITY ........................482

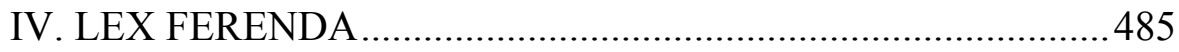

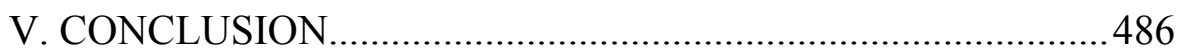

* Lecturer, International Law, The Hague University of Applied Sciences, The Hague, The Netherlands; Research Director, International Law, Bynkershoek Institute, The Hague, The Netherlands; LL.M. (Adv.) in Public International Law, cum laude, Leiden University, Faculty of Law, Leiden, The Netherlands; J.D., Chicago-Kent College of Law, Illinois Institute of Technology, Chicago, Illinois; B.A., Modern European History, University of Kansas, Lawrence, Kansas. 


\section{INTRODUCTION}

International law, and international lawyers generally, tend to take a somewhat conservative approach to the formation of rules. When confronted with the growing availability of leaked information, naturally we might be cautious in considering how the leaks are affecting international law. This paper will assess the growing influence of leaked information on the rules of international law. One of the more pressing issues concerning the increasing prominence of leaked information is criminal responsibility for the leak, in terms of the possible criminal prosecution of WikiLeaks' founder, WikiLeaks' classification as a terrorist organization, and the possible criminal prosecution of people leaking the information in the first place. ${ }^{1}$ The second pressing issue is the legal responsibility under domestic or international law (or in the court of public opinion) for the acts that are documented in the leaks, such as possible criminal prosecution of organizations or individuals implicated in bribery or corruption by government officials, or possible state responsibility for actions depicted in reports on questionable use of military force and extrajudicial killings or war crimes. ${ }^{2}$ However, an additional

1. See In re Pfc. Bradley E. Manning, Charge Sheet (Form DD-458) (July 5, 2010), available at http:/graphics8.nytimes.com/packages/pdf/world/2010/ Manning-charge-sheet.pdf (alleging violations of the Uniform Code of Military Justice, arts. 92, 134; 18 U.S.C. $\S \S 793(e), 1030(a)(1)-(2)$ (2006); Army Reg. 252, ๆศ 4-5(a)(3), 4-6(k)). See generally Gilead Light, The Wikileaks Story and Criminal Liability Under Espionage Laws, 28 WESTLAW J. COMP. \& INTERNET 1 (Sept. 29, 2010) (contending that Julian Assange may be immune to persecution under current U.S. espionage laws).

2. See, e.g., Charlie Savage et al., Classified Files Offer New Insights into Detainees, N.Y. TIMES, Apr. 24, 2011, http://www.nytimes.com/2011/04/25/world/ guantanamo-files-lives-in-an-american-limbo.html (discussing the coercive questioning of Mohammed Qahtani as "[t]he best-documented case of an abusive interrogation at Guantánamo"); see also Doug Meier, Changing with the Times: How Government Must Adapt to Prevent the Publication of Its Secrets, 28 Rev. LiTIG. 203 (2008); Katherine Tsai, How to Create International Law: The Case of Internet Freedom in China, 21 DuKE J. CoMP. \& INT'L L. 401 (2011) (“Google's accusations were confirmed when diplomatic cables leaked to WikiLeaks revealed that the Chinese Politburo directed 'computer sabotage ... [of Google], American government computers, ... Western allies, ... and American businesses.'”) (citing Scott Shane \& Andrew W. Lehren, Leaked Cables Offer Raw Look at U.S. Diplomacy, N.Y. TIMES, Nov. 28, 2010, http://www.nytimes.com/2010/11/29/ world/29cables.html). A related issue is the governmental mission of secrecy and related matters of frank, potentially embarrassing evaluations of situations. See, 
issue, which this author has not seen yet, is a discussion of how the leaked information itself might tell us more about the rules of international law or even change the rules themselves. This paper argues that international lawyers must begin to consider the role of leaked information in the formation and content of the rules of international law.

This paper is not especially focused on WikiLeaks, though it is representative of the phenomenon and the source used primarily for this paper, but it is not unique. ${ }^{3}$ WikiLeaks is the best known example of a new phenomenon, but if it were to disappear tomorrow, it would be replaced. The very decentralized nature of the Internet would provide for it. In addition, major news sources rely on WikiLeaks for their services and have an interest in either supporting its existence or replacing it with a substitute. ${ }^{4}$ Due to the presence of

e.g., Arar v. Ashcroft, 585 F.3d 559 (2d Cir. 2009) (taking judicial notice of the existence of the unclassified report, Office of Inspector General, Dep't of Homeland Sec., (Unclassified) The Removal of a Canadian Citizen to Syria 5, 22, 26-27 (2008), and the statement in the report that "private" diplomatic assurances against torture were received, without disclosing their content); U.S. Dep't State [DOS], Cable No. 09-ROME-649, ๆ 2 (June 9, 2009) (discussing Berlusconi as "feckless, vain, and ineffective as a modern European leader"); DOS Cable No. 09-PRETORIA-2245, 99 (Nov. 3, 2009) (quoting the minister referring to Mugabe as "the crazy old man"); DOS Cable No. 09-TRIPOLI-771 (Sept. 29, 2009) (discussing Qaddafi's eccentricities); DOS Cable No. 09-JEDDAH-443 (Nov. 18, 2009) (describing the double standards of Saudi culture, where the elite youth enjoy "[t]he full range of worldly temptations and vices . . . behind closed doors"); DOS Cable No. 06- MINSK-311, ๆ 1 (Mar. 22, 2006) (painting an unflattering picture of a "clearly disturbed" Lukashenko at a press conference where he gave "bizarre answers"); Afua Hirsch, WikiLeaks Cables Lay Bare US Hostility to International Criminal Court, GuARDIAN, Dec. 17, 2010, http://www.guardian.co.uk/law/2010/dec/17/wikileaks-us-international-criminalcourt (discussing Luis Moreno-Ocampo as having "mediocre English skills"). This problem is not a legal problem per se, but it does shed light on possible reasons for the criminalization of leaking information in the first place.

3. This paper will also contemplate accidental leaks of sensitive, confidential information, though it is less central to this discussion. See, e.g., David Millward \& Thomas Harding, Secrets Put on Internet in Whitehall Blunders, TELEGRAPH, Apr. 17, 2011, http://www.telegraph.co.uk/news/uknews/defence/8457506/Secrets-puton-internet-in-Whitehall-blunders.html.

4. See Mark Davis, Inside Wikileaks, Dateline SBS (Australia), Aug. 1, 2010, available at $\mathrm{http}: / / \mathrm{www}$. sbs.com.au/dateline/story/about/id/600647/n/InsideWikiLeaks (reporting interview with Julian Assange detailing his extensive existing working relationship with major newspapers such as The New York Times, Guardian, and Der Spiegel, including the fact that those newspapers provide 
WikiLeaks and similar players, the availability of leaked information is growing. Much of the information is trivial, but some of it has proved to be important. For example, WikiLeaks' founder Julian Assange has somewhat tenuously claimed that WikiLeaks played a triggering role in the Arab Spring. ${ }^{5}$ Because of the magnitude of leaked information, it is now becoming significant in international affairs.

This paper will walk through the various sources of law, roughly following the Statute of the International Court of Justice ("ICJ"), although some additions may be relevant, and examine each source to see whether and how leaked information might contribute to the formation of law. This paper will not address the validity and accuracy of the ICJ sources, or the other sources mentioned herein, saving that discussion for another day.

\section{SOURCES OF INTERNATIONAL LAW}

The sources of international law are well known and most frequently summarized by reference to the Statute of the ICJ. ${ }^{6}$ These sources include treaties, customary international law, and general principles of law, assisted by judicial decisions and the writings of eminent jurists as subsidiary sources. They are supplemented by unilateral statements as per the Nuclear Tests cases $^{7}$ and obligations incurred under treaties due to certain acts of international organizations, such as binding Chapter VII Resolutions of the U.N. Security Council. This paper will proceed through the various sources to examine how they may be affected by leaked information.

sensitive information to WikiLeaks for it to leak).

5. See Isabel Coles, Assange: WikiLeaks' Cables Spurred Arab Uprisings, REUTERS, Mar. 16, 2011, available at http://www.reuters.com/article/2011/03/16/ us-britain-assange-idUSTRE72E9LO20110316.

6. See Statute of the International Court of Justice art. 38(1), June 26, 1945, 59 Stat. 1055, 1060 [hereinafter Statute of the I.C.J.] ("(a) [I]nternational conventions, whether general or particular, establishing rules expressly recognized by the contesting States; (b) international custom, as evidence of general practice accepted as law; (c) the general principles of law recognized by civilized nations; (d) subject to the provisions of Article 59, judicial decisions and the teachings of the most highly qualified publicists of the various nations, as subsidiary means for the determination of rules of law.").

7. See Nuclear Tests (Aust'l v. Fr.), 1974 I.C.J. 253, ๆ 43 (Dec. 20). 


\section{A. EX TURPI CAUSA NON ORITUR ACTIO}

As a threshold matter, before we turn to an examination of how leaked information might contribute to, or affect the interpretation of, international law, we must consider whether information received through a possibly illegal leak can be relied on in establishing rules.

The Latin expression ex turpi causa non oritur actio ("ex turpi") is usually translated as "a right cannot stem from a wrong." principle is similar to that of ex injuria jus non oritur ("ex injuria") where international law provides that a legal right or entitlement cannot arise out of an unlawful act or omission. ${ }^{9}$ Similar principles are commodom ex injuris sua nemo habere debet (wrongdoer cannot take advantage of his actions) and crimen omnia ex se nata vitiat (property obtained by crime is vitiated). In all of these principles, an actor is forbidden to benefit by the creation of a legal right from his wrongful action.

In the case of leaked information, the information might be obtained wrongfully; however, ex turpi is not applicable to the situation of a leak, nor are its cousins. The principal reason is that a right, advantage, or property must be acquired by the wrongdoer in order to invoke these principles. ${ }^{10}$ If the information was leaked by a government employee or any other person, then that information could still be used by a third party, such as a state, for proving the law. ${ }^{11}$

8. See Diversion of Water from the Meuse (Neth. v. Belg.), 1937 P.C.I.J. (ser. A/B) No. 70 (June 28); Diversion of Water from the Meuse (Neth. v. Belg.), 1937 P.C.I.J. (ser. C) No. 81, $\mid 240$ (June 28); see also Military and Paramilitary Activities in and Against Nicaragua (Nicar. v. U.S.), 1986 I.C.J. 14, ๆ 270 (June 27) [hereinafter Nicaragua Judgment] (Schwebel, J., dissenting); U.S. Diplomatic \& Consular Staff in Tehran (U.S. v. Iran), 1980 I.C.J. 53-55, 62-63 (May 24) (Morozov \& Tarazi, JJ., dissenting); Legal Status of Eastern Greenland (Den. v. Nor.), 1933 P.C.I.J. (ser. A/B) No. 53, at 95 (Apr. 5) (Anzilotti, J., dissenting) ("[A]n unlawful act cannot serve as the basis of an action at law ....").

9. See Accordance with International Law of the Unilateral Declaration of Independence in Respect of Kosovo, Advisory Opinion, 2010 I.C.J. 141 q $132-37$ (July 22) [hereinafter Kosovo Case] (Cançado Trindade, J., separate opinion); HERSCH LAUTERPACHT, RECOGNITION IN INTERNATIONAL LAW 420-21 (1948); Gabčikovo-Nagymaros Project (Hung./Slovak.), 1997 I.C.J. 7, 54, 78 (Sept. 25).

10. See Mavrommatis Jerusalem Concessions (Greece v. U.K.), 1925 P.C.I.J. (ser. A) No. 5 (Mar. 26).

11. See Factory at Chorzów (Germ. v. Pol.) (Claim for Indemnity) (Jurisdiction), 1927 P.C.I.J. (ser. A) No. 9, at 31 (July 26) (“[O]ne Party cannot 
In addition, the wrongdoing in ex injuria is usually considered to be at the level of serious violations of the law, e.g., grave breaches or violations of international humanitarian law, human rights law, or the prohibition on the use of force. ${ }^{12}$ Judge Cançado Trindade, in his separate opinion in the Kosovo Declaration of Independence Advisory Opinion, went so far as to suggest that ex injuria can even be counterbalanced by ex factis jus oritur ("ex factis") when the violations are not of a serious gravity. ${ }^{13}$ Furthermore, those acts are usually considered to contemplate only serious unlawful acts of the state, not acts by private actors. ${ }^{14}$

In any event, all of the foregoing presumes that a leak of

avail himself of the fact that the other has not fulfilled some obligation . . . if the former Party has, by some illegal act, prevented the latter from fulfilling the obligation in question ....”); Mavrommatis Jerusalem Concessions, 1925 P.C.I.J. at 50 ("M. Mavrommatis was bound to perform the acts which he actually did perform in order to preserve his contracts from lapsing as they would otherwise have done.").

12. See Kosovo Case, supra note 9; LAUTERPACHT, supra note 9, at 420-21.

13. See Kosovo Case, supra note 9, ๆథ 136-37 (Cançado Trindade, J., separate opinion).

136. This general principle, well-established as it is, has at times been counterbalanced by the maxim ex factis jus oritur . . . It is inconceivable that States' rights can arise, or be preserved, by means of a consistent pattern of grave violations of human rights and of international humanitarian law.

137. Thus, the maxim ex factis jus oritur does not amount to a carte blanche, as Law plays its role also in the emergence of rights out of the tension between Sollen and Sein. In the present stage of evolution of the law of nations (le droit des gens), it is unsustainable that a people should be forced to live under oppression, or that control of territory could be used as a means for conducting State-planned and perpetrated oppression. That would amount to a gross and flagrant reversal of the ends of the State, as a promoter of the common good.

(citing LAUTERPACHT, supra note 9, at 287-88).

14. See Gerald Fitzmaurice, The General Principles of International Law Considered from the Standpoint of the Rule of Law, in 92-II REC. DES COURS HAGUE ACAD. INT'L L. 119 (1957) ("Thus a State which is guilty of illegal conduct may be deprived of the necessary locus standi in judicio for complaining of corresponding illegalities on the part of other States, especially if these were consequential on or were embarked upon in order to counter its own illegality-in short were provoked by it."). That is not to say that the leaked information could never involve an unlawful act by a state. See, e.g., Vienna Convention on Diplomatic Relations art. 22, ๆ 1, art. 27, Apr. 18, 1961, 500 U.N.T.S. 95 (stating that certain forms of eavesdropping on diplomatic missions by receiving States would be violations of the principle of inviolability of the premises and/or freedom of communication). 
information is unlawful under international law. If the leaking is unlawful under one state's laws, leaking confidential information of that state may still not be unlawful under the laws of other states. In fact, states receiving leaked information might positively condone, endorse, or even encourage such leaks. Since states tend to protect only their own information, it seems difficult to find a rule of customary international law generally prohibiting individuals from leaking information. Domestic law prohibiting leaks is irrelevant without a rule of international law, since a state cannot cite internal laws in defense against international obligations. ${ }^{15}$ In this sense, a state could not invoke its domestic prohibition on leaking information as a defense against the formation or evidence of a rule of international law.

Lastly, the principles cited above apply in situations where the actor relies on the unlawful act for the direct creation of the right or benefit. Here the state relying on the leaked information for proof of a legal norm is not relying on the act of leaking for a right or benefit, but rather the content of the leak. Thus, the state is not relying on the unlawful act itself for any claim or right. We must distinguish a legal claim from a legal rule. The claim relies on the rule, which is evidenced (not created) by the document, which was leaked. Thus, there is no reliance on the act of leaking for a legal right or benefit.

\section{B. THE LAW OF TREATIES}

Under the law of treaties, there are two topics that leaked information can help address: (1) whether a certain communication constitutes a treaty and (2) interpreting the treaty's content.

\section{Definition of a Treaty}

The Vienna Convention on the Law of Treaties (hereinafter

15. See generally Vienna Convention on the Law of Treaties art. 27, May 23, 1969, 1155 U.N.T.S. 331 [hereinafter VCLT]; Avena \& Other Mexican Nationals (Mex. v. U.S.), 2004 I.C.J. 12, 3 (Mar. 31); LaGrand Case (Germ. v. U.S.), Provisional Measures Order, 1999 I.C.J. 9, 16, 928 (Mar. 3); Elettronica Sicula S.p.A. (ELSI), 1989 I.C.J. 51, 73 (July 20); Treatment of Polish Nationals \& Other Persons of Polish Origin or Speech in the Danzig Territory, Advisory Opinion, 1932 P.C.I.J. (ser. A/B) No. 44, 4, 24-25; Draft Articles on State Responsibility, [2001] II-2 Y.B. Int'1 L. Comm'n 31, art. 3 U.N. Doc. A/CN.4/SER.A/2001/Add.1 (Part 2). 
"VCLT" or "Vienna Convention") Article 2(1) provides that:

For the purposes of the present articles: (a) "Treaty" means an international agreement concluded between States in written form and governed by international law, whether embodied in a single instrument or in two or more related instruments and whatever its particular designation.

First, it is important to note that this provision in the VCLT does not necessarily purport to define treaties, but merely states how the term "treaty" is used in the VCLT. ${ }^{16}$ However, the provision in the VCLT has been held to define treaties generally. Thus, we can conclude that there are three elements to the definition of a treaty: (1) that the agreement is concluded between states, (2) that the agreement is made in writing, and (3) that it is governed by international law. In addition, there are two clarifications: (a) that its form in two or more related instruments is irrelevant and (b) that its particular designation is irrelevant.

\section{a. Secret Treaties}

In the specific case of leaked information, the leak could be a leak of a secret treaty, or at least the text of the secret treaty terms. The VCLT merely provides that the instrument must be in writing; it does not require publication or notice. Clearly, the documents leaked by WikiLeaks and similar organizations are written documents, so the issue here is whether the written instrument's secrecy prevents it from being a treaty according to the Vienna Convention's terms.

Whether an instrument is recorded or registered has been suggested as evidence that the instrument was meant to be a treaty. ${ }^{17}$ It is true that states party to the U.N. Charter have an obligation to register their treaties with the organization. However, the consequences of failure to register are not that the treaty is nonbinding, but rather that the treaty cannot be invoked in the UN. ${ }^{18}$ Beyond this obligation, there does not appear to be any obligation for

16. See Comm. of the Whole, 1st Sess., 6th plen. mtg. at 34 q 26, U.N. Doc. A/CONF.39/11 (Apr. 1, 1968) [hereinafter VCLT Conference Recs.].

17. See U.N. Charter art. 102 (providing that instruments are not binding until registered); $c f$. League of Nations Covenant art. 18 (same).

18. See R.B. Lillich, The Obligation to Register Treaties and International Agreements with the United Nations, 65 AM. J. INT. L. 771, 772 (1971). 
states to otherwise publicize their treaties. ${ }^{19}$ While there may be domestic rules on publication, those rules are not applicable on the international plane. ${ }^{20}$ Therefore, as long as the instrument is in writing and otherwise satisfies the elements, the instrument will be a treaty even if it is secret.

\section{b. Non-Legally Binding Agreements}

The second way in which leaked information might lend evidence to whether there is a treaty or not is regarding the binding nature of the agreement. The third element of a treaty, "governed by international law," is still controversial as to whether it requires state intent to be legally binding. The two major voices on either side of this debate are Anthony Aust ${ }^{21}$ and Jan Klabbers. ${ }^{22}$ Aust argues that agreements are only treaties where the parties so intend with other documents being non-binding, "political" agreements, which he terms "Memoranda of Understanding." 23 Klabbers argues that all

19. Georg Schwarzenberger, The Inductive Approach to International Law, 60 HARV. L. REV. 539, 541-42 (1947). The lack of an obligation could affect how we seek to understand and state the law. Schwarzenberger explains the historical reliance on naturalist, deductive methods for determining the law as partly due to the secrecy historically surrounding international power relations. As that intense degree of secrecy has diminished, the deductive method has faded. "Furthermore, then — as today — interstate relations were primarily power relations and demanded a certain degree of secrecy. It required twentieth-century subtlety to find out that secrecy can be as effectively obtained by the publication of floods of material as by burying it in the Tower of London or corresponding places elsewhere. This was the way of the more unsophisticated power politicians up to the end of the seventeenth century." Id. Following Schwarzenberger, perhaps the increased availability of originally secret documents will cause a further drift in international law more completely toward the positivist, inductive approach and away from naturalist, deductive methods. In any event, Schwarzenberger saw secrecy as a normal aspect of international relations that simply had consequences on the techniques for finding the law.

20. See, e.g., Becker v. Préfet de la Moselle Case No. 109 (Trib. De Sarreguemines, Fr., June 22, 1948), reprinted at 38 ReV. CRIT. DE DroIT INT'L PRIVE 55 (1949) (holding that an exchange of letters between France and Germany regarding the nationality of persons in Alsace Lorraine established the intention of the parties, but that they had not been ratified by Parliament, and thus could not modify interpretations of the Treaty of Versailles).

21. Anthony Aust, Modern Treaty Law and Practice ( $2 \mathrm{~d}$ ed., 2007).

22. JAN KLABBERS, THE CONCEPT OF TREATY IN INTERNATIONAL LAW (1996).

23. See Aust, supra note 21, at 49-51. But see KLABBERS, supra note 22, at 53-55 (conceding that even non-binding instruments may have legal 
agreements that satisfy the Vienna Convention are legally binding and that there is no room for "political" agreements between or among states. ${ }^{24}$ For him, intent is not determinative. Most commentators, and the European Court of Human Rights ("ECHR"), appear to agree with Aust, ${ }^{25}$ but interestingly the ICJ (and Permanent Court of International Justice) appear to agree with Klabbers. ${ }^{26}$ In addition, it would appear that states sometimes disagree over whether

consequences).

24. See generally KLABBERS, supra note 22. However, Klabbers does not attempt to address instruments that are expressly designed not to create legal rights and obligations.

25. See, e.g., Sultanov v. Russ., App. No. 15303/09 9 58, Eur. Ct. H.R. (2010) (request for referral to the Grand Chamber pending); Yuldashev v. Russ., App. No. 1248/09 70, Eur. Ct. H.R. (2010); Special Rapporteur, Rep. on Torture and Other Cruel, Inhuman or Degrading Treatment or Punishment, Comm'n on Human Rights, U.N. Doc. A/60/316 51 (Aug. 30, 2005); Human Rights Watch, StiLl AT RisK: Diplomatic Assurances No SAFEguARD Against Torture (2005), available at http://www.hrw.org/node/11783/section/1. It might be argued that in the Nicaragua case, the I.C.J. agreed with Aust. See Military and Paramilitary Activities in and Against Nicaragua (Nicar. v. U.S.), 1986 I.C.J. 14, I 161 (June 27). However, this author understands the court found that the parties (Nicaragua and the Organization of American States) did not reach an agreement, not that they refused to subject their agreement to international law.

26. See Maritime Delimitation and Territorial Questions Between Qatar and Bahrain (Qatar v. Bahr.), 1994 I.C.J. 112, \ 27 (July 1) ("The Court does not find it necessary to consider what might have been the intentions of the Foreign Minister of Bahrain or, for that matter, those of the Foreign Minister of Qatar. The two Ministers signed a text recording commitments accepted by their Governments, some of which were to be given immediate application. Having signed such a text, the Foreign Minister of Bahrain is not in a position subsequently to say that he intended to subscribe only to a 'statement recording a political understanding', and not to an international agreement."); see also Land \& Maritime Boundary Between Cameroon \& Nigeria (Cameroon v. Nigeria; Eq. Guinea intervening), 2002 I.C.J. 303 (Oct. 10) (citing VCLT, supra note 15, art. 46(1), to hold that the applicable agreement constituted a treaty even though the Nigerian Supreme Military Council never ratified it); Land, Island \& Maritime Frontier Dispute (El Sal./Hond.; Nicar. intervening), 1992 I.C.J. 351 (Sept. 11) (finding the boundary agreement binding even though El Salvador had only signed ad referendum); Border and Transborder Armed Acts. (Nic. v. Hond.), 1988 I.C.J. Reps. 69 (Dec. 20) (regarding the Cancun Declaration as legally binding); Continental Shelf (Tunis./Libyan Arab Jamahiriya), 1982 I.C.J. 18, at 70, 9甲 93-95 (Feb. 24) (focusing on the dissenting opinions of judges Ago and Jimenez, which state that the modus vivendi was a treaty); Aegean Sea Continental Shelf (Greece v. Turk.), Juris., 1978 I.C.J. Reps. 3 (stating that no rule prohibiting a joint communiqué from being a legally binding instrument exists). 
an agreement is legally binding, ${ }^{27}$ demonstrating that even in this area there does not appear to be a universal understanding of which agreements are governed by international law. This author has concluded elsewhere that neither of these positions is satisfactory and that we must seek a more nuanced approach to determining whether the instrument was intended to be legally binding. ${ }^{28}$

Leaked information can be very helpful in determining intent to be bound. Whereas certain instruments might on their face appear clear, the formerly secret diplomatic correspondence and negotiating drafts can provide contradictory evidence of the legal value that the parties intend for the instrument to have. Sometimes the intent of states is clear; ${ }^{29}$ other times the states appear simply confused, ${ }^{30}$ perhaps even

27. See, e.g., Heathrow Airport User Charges, Award on the First Question (U.S. v. U.K.), 34 R.I.A.A. 3 (Perm. Ct. Arb. 1992) (noting the United States claim that an MOU was binding in arbitration).

28. See William Thomas Worster, Between Treaty and Not: A Case Study of the Legal Value of Diplomatic Assurances in Expulsion Cases, 21(2) MINN. J. INT'L L. 253 (2012). In this article, the author argues that we start with the understanding that international law applies to all state relations and that states cannot exempt themselves from it, even by agreement. As a corollary, we also start with the presumption that all agreements are governed by international law. We also accept, however, that states may invoke an implied right to enter into nonbinding agreements, though these are construed narrowly. Authors should be explicit in providing for this exception, but such an effect could be implied in rare circumstances. Even where a non-binding effect can be implied, provisions within the agreement might be severable, with certain provisions attracting binding force and others not.

29. See DOS Cable No. 10-PARIS-183 (Feb. 17, 2010) ("French Environment Minister Jean-Louis Borloo told the Ambassador that the key to advancing climate negotiations is to drop the notion of a legally binding TREATY in favor of a system of national commitments. He also argued that it would be up to a small group of eight or ten heads of state, and their sherpas, to negotiate implementation of the Copenhagen Accord. Borloo attributed the European obsession with legally binding treaties to its post-war history and experience in creating the EU by progressively ceding sovereignty via TREATY. The key to reaching this kind of deal would be credible action on tradable quotas, forests, and finance including innovative financing mechanisms. The Copenhagen Accord was not a failure, but allowing the means to become the ends was a trap."); DOS Cable No. 10RIYADH-184, I 11 (Feb. 12, 2010) ("The failed Copenhagen climate change summit produced only a non-binding Accord, but the agreement suits US interests as it presents more chance of forcing China to act .... Prince Abdulaziz told the Minister that Saudi Arabia had missed a real opportunity to submit 'something clever,' like India or China, that was not legally binding but indicated some goodwill towards the process without compromising key economic interests."). 
30. See, e.g., DOS Cable No. 10-THE HAGUE-7, I 3 (Jan. 8, 2010) (containing the draft terms of the US-Dutch Agreement of Cooperation Concerning Access to and Use of Facilities in the Netherlands Antilles and Aruba for Aerial Counter-Narcotics Activities ("FOL"), stating in the same document that the agreement was not legally binding, but then arguing that the agreement "authorized" a certain act and demanded "compliance." "This bilateral agreement allows the USG access to and use of the Hato International Airport in the Netherlands Antilles and the Reina Beatrix International Airport in Aruba ... solely in connection with aerial counter-narcotics detection and monitoring ...."); id. ๆ 2. ("The MFA [Ministry of Foreign Affairs of the Netherlands] has requested a letter signed by the Ambassador confirming that the U.S. abides by the provisions of the March 2, 2000 [Agreement] . . .."); id. I 5 ("Nonetheless, the MFA has requested a letter from the U.S. Ambassador stating the airfields are only being used as authorized in the FOL Agreement."); id. 9 6. ("Still, it is to our benefit to assist the Dutch Government to state explicitly that confirmation of compliance with the FOL Agreement has been received from the U.S."); see also DOS Cable No. 08-MADRID-1280, ๆ 8 (Dec. 4, 2008) (discussing the Agreement on Defence Cooperation ("ADC") between the United States and Spain: "The $\mathrm{ADC}$ provides us the extremely valuable use of two military bases in southern Spain midway between the continental U.S. and the theaters of operation in Afghanistan and Iraq. . . . By unfortunate coincidence, the ADC was already in the press in recent weeks thanks to MOD Chacon's repeated references to her hope that the U.S. would elevate it to the level of a TREATY (septel).”). But see id. ๆ 3 ("El Pais published a February 2007 letter from the Spanish President of the joint Permanent Committee which manages implementation of the ADC, asking the U.S. section to confirm that the U.S. was in compliance with Article 25.2 of the ADC with respect to U.S. military flights to and from Guantanamo . ..."); id. ๆ 9 ("When we do speak publicly on the issue, our mantra is that we have not violated Spanish law and have complied fully with the ADC."); $i d$. 10 ("Thus far, the MOD and MFA have done a reasonably good job in their public affairs efforts of making clear that they do not believe we have violated the ADC. The MOD issued a December 2 statement saying it knew of no U.S. military flights that were either illegal or in violation of our bilateral agreements (this echoes what MOD officials have told us privately - e.g. ref b).”); DOS Cable No. 08-TRIPOLI-308, ๆ 3 (Apr. $10,2008)$. The proposed MOU text is as follows:

Section Six: Dispute Resolution. Any disputes that might arise between the two parties regarding the interpretation or the implementation of this MOU shall be resolved through negotiations between the two parties solely.

‥

Section Nine: Entry into Force, its Scope and Termination

1- This MOU shall enter into force upon its signature by both parties.

2- This MOU does not include any provisions that entail commitments under International Law

3- This MOU shall remain effective unless terminated by a mutual agreement, or by either party, upon 90-day written notice submitted in advance to the other party.

See DOS Cable No. 10-PARIS-183, supra note 29; DOS Cable No. 10-RIYADH184, supra note 29, ๆ 11; DOS Cable No. 10-MADRID-174, ๆๆ 8-11 (Feb. 12, 2010) (discussing the 1998 Washington Conference on Nazi Confiscated Art and 
sloppy ${ }^{31}$ which is informative in itself as to the legal value of the instrument.

\section{Interpretation of Treaty Terms}

The other way in which leaked information might influence the rules of international law is where the information bears on the interpretation of treaty provisions.

\section{a. Fruit of the Poisonous Tree}

Earlier we examined the rule of ex turpi, but another rule is important here: "the fruit of the poisonous tree." 32 This rule prohibits the introduction of evidence against a party where it was gained unlawfully. Thus the evidence - at least in U.S. practice - is subject to an exclusionary rule. We can distinguish this rule from that of $e x$

the 2009 Prague Conference on Nazi Confiscated Art, and the U.S. signature on the "Declarations of Principles" in the context of the Cassirer claim to a Pissarro painting; acknowledging the signature on the Declaration of Principles but stating that Spain could rely on its internal law to bar the claim-not possible if the agreement was concluded under international law — and seek alternate "creative solutions" amounting to "gestures to the family and to the Los Angeles Jewish community"); DOS Cable No. 09-KYIV-1942, ๆף 6, 54 (Nov. 9, 2009) (discussing "security assurances": "The first item Nykonenko raised during the one-onmeeting was an appeal for additional security assurances for Ukraine, beyond those the U.S. had provided in the 1994 Budapest Declaration . . . Legally binding assurances were best, he concluded, but he said he understood this was very difficult. Couch asked Nykonenko to explain why Ukraine needed additional, legally binding security assurances, ... Nykonenko responded that Ukraine had no doubts about the commitment of the United States; however, Ukraine had serious concerns about Russia's commitment ... Nykonenko explained that if the United States would agree to new security assurances with Ukraine, then Russia would likely agree to join in the document ....").

31. See DOS Cable No. 10-PORT LOUIS-46, ๆ 2 (Feb. 17, 2010) (comingling discussions about considerations for an exchange of letters and an MOU, which, although the MOU and the exchange of letters are expressly identified as such, could suggest a less rigorous division between the two in practice). "Also, Seychelles now has both an MOU with the UK and an exchange-of-letters with the European Union regarding pirate transfer/prosecution. Given these developments, Embassy believes it is now time to pursue a U.S./Seychelles MOU on pirate transfer/prosecution"). Id.; DOS Cable No. 10-PORT LOUIS-48 (Feb. 17, 2010) (continuing discussion on the same topic).

32. See, e.g., Wong Sun v. United States, 371 U.S. 471, 484-85 (1963) (providing that "evidence seized during an unlawful search could not constitute proof against the victim of the search"). 
turpi. In ex turpi, the wrong itself creates the claim of a right, whereas under the fruit of the poisonous tree the wrong produces evidence pertaining to a right. For the reasons discussed below, the fruit of the poisonous tree rule is not applicable to proof of the law here.

Firstly, it is unclear if the fruit of the poisonous tree, especially in its strong form as an exclusionary rule, exists as a rule under international law. ${ }^{33}$ This author is not aware of any international treaties that mandate an exclusionary rule in state-to-state dispute settlement for evidence gathered in the course of violating the law generally. International human rights conventions have provided that states must respect individuals' human rights and provide a right to an effective remedy - right to an impartial tribunal and right to a fair hearing-for violations, though not necessarily a remedy of exclusion of evidence. ${ }^{34}$ The Rome Statute of the International Criminal Court ("ICC"), and its accompanying Rules of Procedure and Evidence, provide that the court may exclude evidence from trial where the risk of prejudice outweighs the probative value of the evidence sufficient to undermine the right to a fair trial. ${ }^{35} \mathrm{In}$ particular, evidence may be excluded where there was a violation of

33. Most commentators identify the role of the jury in common law proceedings as the crucial determining factor for rules of evidence, and especially exclusion. See, e.g., International Conference on Military Trials: London, 1945Minutes of Conference Session of June 26, 1945, YALE LAW SCHOOL, http://avalon.law.yale.edu/imt/jack13.asp (last visited Sept. 18, 2012) (citing Robert Jackson: "The idea may have more significance to British and American lawyers than it does to Continental lawyers. . . . We do not want technical rules of evidence designed for jury trials to be used in this case to cut down what is really and fairly of probative value ..."). However, the form and manner in which the rule is applied in common law practice does not mean that similarly obtained evidence is always admissible in the courts of civil law states. See, e.g., Gäfgen v. Germ., App. No. 22978/05 9 147, 2010 Eur. Ct. H.R. 759 (2010) (holding that Article 6 of the European Convention on Human Rights - regarding the right to a fair trial-does not impose particular rules of exclusion of evidence, but instead requires that the trial overall is fair, so only a direct causal link between the unlawful treatment by the state and the conviction was problematic).

34. See Universal Declaration of Human Rights art. 8, G.A. Res. 217 (III) A, U.N. Doc. A/RES/217 (III) (Dec. 10, 1948); International Covenant on Civil and Political Rights arts. 2(1)-2(2), 14(1), Dec. 16, 1966, 999 U.N.T.S. 171, S. Treaty Doc. 95-20.

35. Rome Statute of the International Criminal Court art. 69(4), July 17, 1998, 2187 U.N.T.S. 90. 
the Rome Statute or international human rights law, and that violation raises "substantial doubt on the reliability of the evidence or ... the admission of the evidence would be antithetical to and would seriously damage the integrity of the proceedings." ${ }^{36}$ The laws of the local jurisdiction where the evidence was gathered is not determinative on the assessment by the ICC. ${ }^{37}$ Generally, the state is free to address the remedy for wrongfully gained evidence within the context of its particular legal system, where the solution might be exclusion or not. ${ }^{38}$

However, some treaties do provide specifically for the exclusion of evidence gained by committing acts that the treaty prohibits, uniquely torture. ${ }^{39}$ The Eighth Congress on the Prevention of Crime and the Treatment of Offenders agreed on non-binding guidelines for prosecutors recommending that evidence be excluded where it has been obtained through the use or threat of torture or similar coercion. ${ }^{40}$ Even if exclusion of evidence in this case could be considered a binding rule under international law, it appears to be limited only to torture.

Turning to customary international law, there also does not appear

36. Id. art. 69(7).

37. Id. art. 69(8).

38. International Covenant on Civil and Political Rights, supra note 34, art. 2(3) ("Each State Party to the present Covenant undertakes: (a) to ensure that any person whose rights or freedoms as herein recognised are violated shall have an effective remedy, notwithstanding that the violation has been committed by persons acting in an official capacity; (b) To ensure that any person claiming such a remedy shall have his right thereto determined by competent judicial, administrative or legislative authorities, or by any other competent authority provided for by the legal system of the State, and to develop the possibilities of judicial remedy; (c) to ensure that the competent authorities shall enforce such remedies when granted.").

39. Convention Against Torture and Other Cruel, Inhuman or Degrading Treatment or Punishment art. 15, Dec. 10, 1984, 1465 U.N.T.S. 85.

40. See Guidelines on the Role of Prosecutors, 8th U.N. Congress on the Prevention of Crime \& the Treatment of Offenders, Aug. 27, 1990-Sept. 7, 1990, art. 16, U.N. Doc. A/CONF.144/28/Rev.1, 189 (1990) ("When prosecutors come into possession of evidence against suspects that they know or believe on reasonable grounds was obtained through recourse to unlawful methods, which constitute a grave violation of the suspect's human rights, especially involving torture or cruel, inhuman or degrading treatment or punishment, or other abuses of human rights, they shall refuse to use such evidence against anyone other than those who used such methods ...."). 
to be an exclusionary rule for evidence gained unlawfully. We can begin our assessment of customary international law by examining the jurisdiction(s) where the rule is most vigorously applied: the United States, and to a lesser degree other common law jurisdictions. ${ }^{41}$ Looking first at U.S. law, it is interesting to note that Justice Frankfurter, writing for the majority in Wolf in the course of analyzing whether the fruit of the poisonous tree must be excluded from evidence as being "implicit in ordered liberty," referred to the practice of other states and argued that:

[T] he immediate question is whether the basic right to protection against arbitrary intrusion by the police demands the exclusion of logically relevant evidence obtained by an unreasonable search and seizure because, in a federal prosecution for a federal crime, it would be excluded. As a matter of inherent reason, one would suppose this to be an issue to which men with complete devotion to the protection of the right of privacy might give different answers. When we find that in fact most of the English-speaking world does not regard as vital to such protection the exclusion of evidence thus obtained, we must hesitate to treat this remedy as an essential ingredient of the right. ${ }^{42}$

Frankfurter cited the practice of the UK and other common law jurisdictions to conclude that exclusion was not the usual practice internationally ${ }^{43}$ and was also not a part of the common law. Additionally, this acknowledgement means that when Wolf was overturned in Mapp, and the exclusionary rule was upheld, ${ }^{44}$ the United States became the only common law jurisdiction that had

41. See New York v. Harris, 495 U.S. 14, 18 (1990); Murray v. United States, 487 U.S. 533, 536-37 (1988); Taylor v. Alabama, 457 U.S. 687 (1982); Dunaway v. New York, 442 U.S. 200 (1979); Brown v. Illinois, 422 U.S. 590 (1975); Wong Sun v. United States, 371 U.S. 471, 484-85 (1963); Mapp v. Ohio, 367 U.S. 643 (1961); Silverman v. United States, 365 U.S. 505 (1961); Wolf v. Colorado, 338 U.S. 25 (1949); Nardone v. United States, 308 U.S. 338, 341 (1939); Weeks v. United States, 232 U.S. 383 (1914).

42. See Wolf, 338 U.S. at 25.

43. See id. at App. (citing Miller v. Noblet [1927] SASR 385 (Austl.); R. v. Nelson, [1922] 2 W.W.R. 381, 69 D.L.R. 180 (Can.); Durousel, 41 Man. 15, [1933] 2 D.L.R. 446 (Man.); R. v. Doyle, 12 Ont. 347 (Ont.); R. v. Kostachuk, 24 Sask. 485, 54 Can. C.C. 189 (Sask.); Elias v. Pasmore, [1934] 2 K.B. 164 (Eng.); Ali Ahmad Khan v. Emp., 81 I.C. 615(1) (Ind.); Baldeo Bin v. Emp., 142 I.C. 639 (Calcutta); Chwa Hum Htive v. Emp., 143 I.C. 824 (Rangoon); Hodgson v. McPherson, [1913] S.C.(J.) 68, 73 (Scot.)).

44. See Mapp, 367 U.S. at 655. 
adopted a mandatory exclusionary rule for evidence obtained from an unlawful search and seizure. ${ }^{45}$ Until Mapp in 1961, the United States held that the exclusionary rule, as a rule of remedy, was applicable only at the discretion of state legislatures. ${ }^{46}$

In addition, the exclusionary rule for wrongfully gathered evidence is not absolute. There are exceptions to the rule, such as the inevitable discovery rule. This rule provides that, where the evidence that is tainted by the violation of the law inevitably would have been or was discovered later, it will not be excluded simply because it was, or was initially, discovered through the violation. ${ }^{47}$ Some exceptions to the exclusionary rule have been reversed. Since this is an examination of the rule under international law rather than specifically under U.S. law, rules that have been reversed remain informative of the rule at international law. One major exception that was later reversed was the Silver Platter rule, in which evidence unlawfully obtained by state officials and barred as evidence could nonetheless be used by federal government officials, since they had not committed the prohibited acts. ${ }^{48}$ This rule was reversed in $1960 .{ }^{49}$ The exceptions to the rule, ${ }^{50}$ even if mostly historical, suggest that the rule is not absolute and can be abridged.

In sum, U.S. law generally provides for application of the exclusionary rule under the principle of "fruit of the poisonous tree" only where the case is one of criminal law. ${ }^{51}$ When applied, it involves protection from the state (government officials) ${ }^{52}$ against

45. See, e.g., Minister of Finance v. Braswell, 132 INT’L L. REPS. 237, 269 \ 78 (Berm. Ct. App., Nov. 28, 2002) ("'[T]he 'fruits of the poisonous tree' principle under the Miranda rule of US law . . . is not a rule applied in the English or Bermuda courts.").

46. Also note that, following Wolf, the exclusionary rule as a remedy for unlawful searches or seizures was not mandatory for the states until Mapp made it mandatory.

47. See Nix. v. Williams, 467 U.S. 431, 459 (1984).

48. See Lustig v. United States, 338 U.S. 74, 79 (1949) (discussing the "silver platter" doctrine).

49. See Elkins v. United States, 364 U.S. 206 (1960).

50. See, e.g., Silverthorne Lumber Co. v. United States, 251 U.S. 385, 392 (1920) (articulating the "independent source" doctrine).

51. See Roe v. Harvey, [1769] 98 Eng. Rep. 302, 305 (Engl., K.B.) (distinguishing the court's ability to compel a party to produce inculpatory evidence in a civil suit from a criminal case).

52. See Nix, 467 U.S. at 442-43 (1984) ("The core rationale consistently 
torture, compulsion, or similar violation of fundamental ("constitutional") rights. ${ }^{53}$ However, even where all of these aspects are met, exclusion is not always a mandatory remedy. ${ }^{54}$

Other common law jurisdictions make provision for the exclusion of evidence obtained in violation of the law but do not adopt such a categorical perspective on exclusion. In general, the common law, as applied in various commonwealth countries, admitted anything into evidence that was relevant, probative, and reliable, and it disregarded the way in which the evidence came into the possession of the party submitting it. ${ }^{55}$ The judge, however, did have a general discretion to exclude evidence where the probative value was outweighed by its prejudicial potential, but this was largely a question of reliability of the evidence. ${ }^{56}$ It would appear that the American approach is essentially focused on the rights of the accused, whereas other common law jurisdictions concentrate on the fairness and legitimacy of the trial proceedings generally.

In the UK, the treatment is consistent with the general common

advanced by this Court for extending the exclusionary rule to evidence that is the fruit of unlawful police conduct has been that this admittedly drastic and socially costly course is needed to deter police from . . . violations of constitutional and statutory protections. This Court has accepted the argument that the way to ensure such protections is to exclude evidence seized as a result of such violations notwithstanding the high social cost of letting persons obviously guilty go unpunished for their crimes. On this rationale, the prosecution is not to be put in a better position than it would have been in if no illegality had transpired."'); Warden v. Hayden, 387 U.S. 294, 301 (1967) ("[The Fourth Amendment was] intended to protect against invasions of 'the sanctity of a man's home and the privacies of life,' from searches under indiscriminate, general authority. Protection of these interests was assured by prohibiting all 'unreasonable' searches and seizures, and by requiring the use of warrants, which particularly describe 'the place to be searched, and the persons or things to be seized,' thereby interposing 'a magistrate between the citizen and the police'....") (internal citations and footnotes omitted).

53. See Nix, 467 U.S. at 442-43 (1984); United States v. Wade, 388 U.S. 218, 242 (1967); Wolf v. Colorado, 338 U.S. 25 (1949); R v. Rudd, [1775] 168 Eng. Rep. 160 (Engl., K.B.).

54. See Hudson v. Michigan, 547 U.S. 586 (2006); Colorado v. Connelly, 479 U.S. 157, 166 (1986); United States v. Leon, 468 U.S. 897, 907-08 (1984); United States v. Calandra, 414 U.S. 338, 348 (1974).

55. See R. v. Leatham, [1861] Q.B. 495 (Eng.) ("It matters not how you get it; if you steal it even, it would be admissible in evidence.")

56. See Adam Parachin, Compromising on the Compromise: The Supreme Court and Section 24(2) of the Charter, 10 WINDSOR REV. LEG. \& Soc. ISSUES 7, 13 (2000). 
law approach, which is concerned with the administration of justice or general unfairness to the defendant ${ }^{57}$ rather than providing a remedy for a violation of rights. ${ }^{58}$ However, unfairness is not a question of rights, but a question of the probative value of the evidence. ${ }^{59}$ Where it is probative, judges rarely, if ever, exclude it.

Canada's exclusionary practice resembles that of the UK. The Canadian Charter of Rights and Freedoms provides that evidence obtained in violation of an accused's civil rights may be excluded only if the admission of the evidence would bring the administration of justice into disrepute. ${ }^{60}$ Even prior to the Charter, Canada applied a similar rule of exclusion when the administration of justice would be brought into disrepute. ${ }^{61}$ In this way, the Canadian courts, like those of the UK, were concerned with reliability and probative value, not remedying violations of rights. ${ }^{62}$ After the "patriation" of the Canadian Constitution, the Charter provided for extensive rights including the rights against unreasonable search and seizure, ${ }^{63}$ arbitrary detention, ${ }^{64}$ prevention from retaining or instructing

57. See Fox v. Ch. Constable, [1985] 3 All E.R. 392, 397 (U.K., H.L.) (“The duty of the court is [to decide if the accused is guilty], and not to discipline police for exceeding their powers."); R v. Sang, [1980] App. Cas. 402, 436 (C.A., U.K., 1979); K. v. R, [1968] 52 Crim. App. R. 353, 358 (U.K., P.C.); Kuruma v. R, [1955] P.C. 197, 237-40 (Eng.) (appeal taken from E. Afr.); Jones v. Owens, [1870] 34 Q.B. 759, 760 (Eng.) ("[I]t would be a dangerous obstacle to the administration of justice . . . to hold because evidence was obtained by illegal means it could not be used against a party charged with an offense.").

58. See Kuruma, [1955] P.C. at 239.

59. See Callis v. Gunn, [1963] 48 A.C. 36, 40-41 (Eng., Q.B.) (holding that the court may exclude evidence obtained "by a trick, by threats, [and] by bribes"); R. v. Payne, [1963] 47 A.C. 122 (Eng.) (excluding evidence when defendant relied on officer's assurance that the evidence would not be used).

60. Canadian Charter of Rights and Freedoms, Part I of the Constitution Act, 1982, being Schedule B to the Canada Act, 1982, c. 11, § 24(2) (U.K) ("Where, in proceedings under subsection (1), a court concludes that evidence was obtained in a manner that infringed or denied any rights or freedoms guaranteed by this Charter, the evidence shall be excluded if it is established that, having regard to all circumstances, the admission of it in the proceedings would bring the administration of justice into disrepute.").

61. See R. v. Rothman, [1981] 1 S.C.R. 640, 698 (Can.) (Lamer, J.).

62. See R. v. Wray, [1971] S.C.R. 272, 273-77 (Can.) ("[E]xcluding evidence . . . obtained by methods which the trial Judge considers to be unfair . . would have nothing to do with securing a fair trial for the accused.").

63. Canadian Charter, $\S 8$.

64. Id. $\S 9$. 
counsel, ${ }^{65}$ failure to be informed of the specific offence charged, ${ }^{66}$ and subjection to cruel and unusual treatment or punishment. ${ }^{67}$ The Charter also provides remedies for these violations, ${ }^{68}$ which requires exclusion only when admission "[c] ould bring the administration of justice into disrepute." ${ }^{69}$ Thus, there is a two-step analysis: first, the court must determine whether there was a violation of a Charter right. Second, if there is a violation, the court must determine whether the violation brings the administration of justice into disrepute. $^{70}$ This second step of the analysis looks to factors such as the fairness of the trial (i.e., whether the evidence is probative or not, and whether it would have been eventually discovered or not), the seriousness of the Charter violation, and the effect on the administration of justice.

The difficulty with all of the above is that, first, it is apparent that a mandatory exclusionary rule is not the norm globally or the norm under common law and, second, where exclusion is considered, it is only in the face of a violation of the rights of a human being by the state in criminal proceedings. These concerns do not apply in the case of state-to-state litigation. Here the issue is whether a state may rely on evidence against another state where the evidence was obtained in violation of the law.

However, when we turn to the case law of civil law jurisdictions and international tribunals applying customary international law, the rule virtually disappears, aside from the unique case of torture. ${ }^{71}$ The International Criminal Tribunal for the former Yugoslavia ("ICTY") (reviewing customary international law) ${ }^{72}$ and the ECHR (reviewing

65. Id. § 10(a)-(b).

66. Id. $\S 11(\mathrm{a})$.

67. Id. $\S 12$.

68. Id. § 24(1) ("Anyone whose rights or freedoms, as guaranteed by this Charter, have been infringed or denied may apply to a court of competent jurisdiction to obtain such remedy as the court considers appropriate and just in the circumstances.").

69. Id. $\S 24(2)$.

70. See R. v. Stillman, [1997] 1 S.C.R. 607 (Can.); R. v. Hebert, [1990] 2 S.C.R. 151, 178 (Can.); R. v. Collins, [1987] 1 S.C.R. 265 (Can.).

71. For an excellent analysis of the rule in comparative law, see generally, Stephen C. Thaman, "Fruits of the Poisonous Tree" in Comparative Law, 16 Sw. J. INT'L L. 333 (2010).

72. In this context, it is important to note that the ICTY rules on evidence also 
German law $)^{73}$ do not exclude evidence automatically where the evidence may have been obtained unlawfully. In addition, in interstate disputes, the ICJ has indirectly ruled on exclusion of evidence obtained in violation of international law in the Corfu Channel case. ${ }^{74}$ The court held that the minesweeping operation, "Operation Retail," was an unlawful violation of Albanian territorial waters ${ }^{75}$ however, the court accepted the evidence submitted by the UK and relied on it for its judgment of the mines it discovered in the course of that unlawful operation. ${ }^{76}$ Since the court did not hesitate to

make reference to protection of the right to a fair trial, not specific rules of exclusion. See, e.g., International Tribunal for the Prosecution of Persons Responsible for Serious Violations of International Humanitarian Law Committed in the Territory of the Former Yugoslavia Since 1991, Rules of Procedure and Evidence, U.N. Doc. IT/32/Rev.46 (2011), Rule 89(C) ("A Chamber may admit any relevant evidence which it deems to have probative value."); Rule 89(D) (“A Chamber may exclude evidence if its probative value is substantially outweighed by the need to ensure a fair trial."); Prosecutor v. Jelisić, Case No. IT-95-10-A, Judgement, ๆๆ 34-37 (Int'l Crim. Trib. For the Former Yugoslavia, July 5, 2001); Prosecutor v. Delalić et al. (“Čelebici case”), Case No. IT-96-21-A, Judgement, ๆ 434 (Int'l Crim. Trib. for the Former Yugoslavia, Feb. 20, 2001); Prosecutor v. Blaškić, Case No. IT-95-14-T, Judgement, $₫ 34$ (Int'l Crim. Trib. for the Former Yugoslavia, Mar. 3, 2000); Prosecutor v. Jelisić, Case No. IT-95-10-T, Judgement, I 108 (Int'l Crim. Trib. for the Former Yugoslavia, Dec. 14, 1999). Furthermore, the European Convention on Human Rights protects the same. See Gäfgen v. Germany, App. No. 22978/05 147, 2010 Eur. Ct. H.R. 759 (2010).

73. See, e.g., id. (holding that Article 6 of the European Convention on Human Rights - regarding the right to a fair trial-does not impose particular rules of exclusion of evidence, but instead requires that the trial overall be fair, so that only a direct causal link between the unlawful treatment by the state and the conviction is problematic); Jalloh v. Germany, App. No. 54810/00, Eur. Ct. H.R. (2006) (finding a trial to be unfair where evidence was obtained by the state in the course of violating Article 3 of the ECHR - torture, inhuman or degrading treatment-so that the evidence should never have been admitted at trial regardless of probative value).

74. Corfu Channel, (U.K. /Alb.), 1949 I.C.J. 4 (Apr. 9).

75. See id. at 35 ("Between independent States, respect for territorial sovereignty is an essential foundation of international relations. The Court recognizes that the Albanian Government's complete failure to carry out its duties after the explosions, and the dilatory nature of its diplomatic notes, are extenuating circumstances for the action of the United Kingdom Government. But to ensure respect for international law, of which it is the organ, the Court must declare that the action of the British Navy constituted a violation of Albanian sovereignty.").

76. See id. at 13-15 (establishing that the location of the mine sweeping of two ships happened in Albania's territorial waters based on evidence presented by the United Kingdom). 
accept evidence that had been gathered in what was, according to the court in the same opinion, a violation of international law, it is difficult to see how the exclusionary rule of the "fruit of the poisonous tree" applies under international law. ${ }^{77}$

A final observation is that, in all of the cases discussed above, when the violation was considered to be sufficient to trigger an exclusionary rule, the violation was a violation of law in the legal system within which the tribunal is operating and assessing the evidence obtained. The evidentiary rule at the ICC goes so far as to make this limitation clear: a violation of state law will not be determinative of whether evidence is admitted before the ICC unless that violation is also a violation of international law. ${ }^{78}$ Therefore, even if we concluded that the fruit of the poisonous tree applied under international law, it would only prohibit evidence obtained through a violation of international law.

In sum, the mandatory exclusionary rule for evidence gathered unlawfully does not appear to exist under international law. If it does exist under international law at all, it appears to operate only for the benefit of natural persons, not states, and can only be invoked where the evidence was gathered in violation of international law, not municipal law. Finally, in those few cases where the rule would apply, the violation would not result in an automatic exclusion of evidence. Instead, the evidence would only be excluded where it was gathered in a manner that renders it substantially unreliable and reliance on the evidence would cast serious doubt on the integrity of the proceedings. ${ }^{79}$

In the case of leaked information, none of these concerns apply. It is debatable whether the leaking of information is a violation of domestic law, but it is certainly not a violation of international law. It could be that the fact that the evidence was leaked might affect its reliability; however, so far we have not heard authorities denying the authenticity of the leaked information, just attacking the lawfulness

77. See id. at 35 ("To ensure respect for international law, of which it is the organ, the Court must declare that the action of the British Navy constituted a violation of Albanian sovereignty.").

78. See Rome Statute of the International Criminal Court, supra note 35, art. 69(7).

79. Id. 
or morality of the leak. ${ }^{80}$ Lastly, the leaked information in this argument would be admitted to prove the existence of law, not fact. Clearly this distinction is not the easiest to maintain where the existence of the law could be a fact, and the International Law Commission ("ILC") discussion of the sources of evidence of customary international law does not appear to make any distinction. ${ }^{81}$ However, even if we would somehow find any of the foregoing concerns reason to doubt the admissibility of evidence, we must still pause to consider whether admissibility of evidence is ever a concern for the proof of law, not fact.

That being said, there are two caveats for the use of leaked information that might be especially important for leaked information and international law. The first is that documents of evidence (not proof) should be assessed as such. Internal memoranda and diplomatic correspondence and cables to the foreign ministries might be showing internal disagreements and discussions, often separated from context. ${ }^{82}$ The second concern is that leaked information might be purposefully leaked as a part of a campaign of

80. Cf. Key Reaction to Wikileaks Cables Revelations, BBC (Nov. 29, 2010), www.bbc.co.uk/news/world-us-canada-11866220 (documenting the reaction to WikiLeaks of world leaders, who condemned the information leaks as hazardous to foreign policy interests); Charlie Savage, U.S. Weighs Prosecution of WikiLeaks Founders, but Legal Scholars Warn of Steep Hurdles, N.Y. TIMES (Dec. 1, 2010), www.nytimes.com/2010/12/02/world/02legal.html?_r=1 (reporting that the U.S. Department of Justice was contemplating pursuing legal action against Assange).

81. See Rep. of the Int'l Law Comm'n, 5th Sess., June 5-July 29, 1950, Ways and Means for Making the Evidence of Customary International Law More Readily Available, at 4, ๆๆ 33-89, U.N. Doc. A/1316 (SUPP) (1950) (discussing texts of treaties and conventions, decisions of international courts and tribunals, decisions of national courts, national legislation, diplomatic correspondence, opinions on questions of international law given by legal advisers to governments, and the practice of international organizations); see also Special Tribunal for Lebanon, Case No. STL-11-01/I, Interloc. Dec. on the Appl. Law, 97 (App. Chambers, Feb. 16, 2011) (finding that the existence of customary international law had been shown "beyond any shadow of doubt" without, however, determining that that is the applicable burden of proof).

82. See, e.g., Nicaragua Judgment, supra note 8, at 41 (holding that statements by officials, especially when unfavorable, should be treated with "caution"); Ways and Means for Making the Evidence of Customary International Law More Readily Available, supra note 81, at 8, १ฯ 75-76 (urging caution when relying on "State papers," as the contents may be deceiving because "arguments are often contentiously put forth which by no means represent the eventual view of the government"). 
disinformation. ${ }^{83}$ If those concerns, among others, were taken into consideration in researching the law, and the actor assessing the law made the assessment objectively and responsibly, then it is difficult to see how the law thus found should be open to challenge.

\section{b. Ordinary Meaning, Context, and Object and Purpose}

Having concluded that leaked documents might contain treaty obligations themselves, the next inquiry under the law of treaties is the degree to which information in leaked documents might inform our understanding of other treaty obligations. This section will first look at the special meaning and then general meaning of treaty terms.

Article 31(4) of the VCLT provides that: "A special meaning shall be given to a term if it is established that the parties so intended." It has not been established what sources are permissible for a special meaning. The commentary to the VCLT suggests that a special meaning could be established by context, with the debate focusing instead on the party bearing the burden of proof for establishing a special meaning. ${ }^{84}$ Surely leaked information might inform us of a special meaning.

However, where a term does not have a special meaning, Article 31(1) of the VCLT commands that "[a] treaty shall be interpreted in good faith in accordance with the ordinary meaning to be given to the terms of the treaty in their context and in the light of its object and purpose."

While the term "ordinary meaning" might appear at first glance to be clear, it dissolves on greater scrutiny. Delegates to the Conference on the Law of Treaties noted as much. ${ }^{85}$ The VCLT commentary

83. For example, the Uribe administration in 2008 was alleged to have carefully planned the leaking of information from computers of killed FARC commander Raul Reyes to link Venezuelan President Hugo Chavez and Ecuadorean President Rafael Correa to the rebel group.

84. See Int'1 L. Comm'n, Draft Articles on the Law of Treaties with Commentaries, II Y.B. INT'L L. COMM'N. 187, art. 31 (1966), U.N. Doc. A/CN.4/SER.A/1966/Add.1 (ex-27), commentary (17) [hereinafter VCLT Commentaries] (describing how some parties wanted to put the burden of proving the special meaning of a term on the party who wanted to use that special meaning); VCLT Conference Recs., supra note 16, at 33d Mtg, 14 (as per Zemanek).

85. See VCLT Conference Recs., supra note 16, at 32d Mtg, 98 (as per 
argues that the ordinary meaning is the meaning in context and with regard to the object and purpose of the treaty, partly derived from the treaty preamble. $^{86}$ Therefore, the ordinary meaning cannot be divorced from the object and purpose and context. ${ }^{87}$ Here, as well, leaked information could shed light on the object and purpose of the treaty, perhaps even guiding us on the "ordinary meaning."

Continuing with Article 31 of the VCLT, paragraph (2) instructs:

The context for the purpose of the interpretation of a treaty shall comprise, in addition to the text, including its preamble and annexes:

(a) any agreement relating to the treaty which was made between all the parties in connection with the conclusion of the treaty;

(b) any instrument which was made by one or more parties in connection with the conclusion of the treaty and accepted by the other parties as an instrument related to the treaty.

Although using the expression "treaty" in this provision, the VCLT also embraces the expressions "agreement" and "instrument," suggesting that these are something other than treaties. Given that the VCLT was specifically about "treaties" and contained a definition of the term, we can guess that the term has particular significance, so where the drafters of the Vienna Convention used different terms, the usage must be meaningful. ${ }^{88}$ The terms "agreement" and "instrument," suggest a broader scope of communications that may be considered in establishing the context of the treaty. Once again, leaked information might prove to be relevant.

The important point for this provision is that context is not only to be considered when there is ambiguity, but rather that context is part of determining the ordinary meaning of the words. ${ }^{89}$ The ILC stated

Krispis) (noting that, because one word usually has multiple meanings, the Greek representatives did not think it possible to rely on a word's ordinary meaning).

86. VCLT Commentaries, supra note 84, art. 31 (ex-27), commentary (12).

87. See VCLT Conference Recs., supra note 16, at 33d Mtg., 7 (relaying that the ordinary meaning of a word is derived from its usage and context throughout the entire treaty).

88. See VCLT Conference Recs., supra note 16, at 33d Mtg. ๆ 30 (indicating that interpretation of a treaty should depend exclusively on documents written in relation to the treaty's construction and adoption).

89. VCLT Commentaries, supra note 84, art. 31 (ex-27), commentary (13). 
that the preamble of a treaty is very clearly part of its context, ${ }^{90}$ but the real issue is whether other documents (and, if so, which documents) could also form part of the context. ${ }^{91}$ The commentary to the Vienna Convention reaffirms that Article 31(2)(a) identifies two types of documents that can form context. ${ }^{92}$ The commentary clarifies that the crucial factor for both (a) and (b) is partly that they are not unilateral statements, ${ }^{93}$ although unilateral statements could form context where their "relation to the treaty was accepted in the same manner by the other parties." 94

\section{c. Subsequent Practice}

Lastly, communications can influence the interpretation of treaty terms where the communications are subsequent agreements regarding the interpretation of the treaty itself. Article 31(3) of the VCLT states: "There shall be taken into account, together with the context: (a) any subsequent agreement between the parties regarding the interpretation of the treaty or the application of its provisions ...." The ILC identified as a question of fact whether an understanding during negotiations was meant to be an agreement for interpreting a treaty term, though it did not find it controversial that an understanding agreed prior to, contemporary with, or following the conclusion of a treaty could be considered an integral part of the treaty. ${ }^{95}$ If a leaked document could be considered a subsequent agreement, then it could fall under this rule.

However, in addition to subsequent agreements, Article 31(3)(b) of the Vienna Convention also provides that subsequent practice can

90. Id.

91. Id. See also VCLT Conference Recs., supra note 16 (as per Samad).

92. VCLT Commentaries, supra note 84, art. 31 (ex-27), commentary (14) (recounting that the two types of documents that can show context are "(a) any agreement relating to the treaty which was made between all the parties in connexion [sic] with the conclusion of the treaty; and (b) any instrument which was made in connexion [sic] with the conclusion of the treaty and accepted by the other parties as an instrument related to the treaty").

93. Id.

94. Id.

95. See id. cmt. 14 (quoting Ambatielos (Greece v. U.K.) Judgment, 1952 I.C.J. 28, 43, 75 (July 1)) ("[T]he provisions of the Declaration are in the nature of an interpretation clause, and, as such should be regarded as an integral part of the Treaty ...."). 
be considered. ${ }^{96}$ Discussions, understandings, and even memoranda of understanding might be communicated in secret documents that are later leaked. In the sections above, it has already been discussed whether a secret, leaked MOU could be considered a treaty (or other agreement), but even if it could not, it might still qualify as subsequent practice. In the Heathrow Airport User Charges arbitration, the United States and United Kingdom argued over whether an MOU, concluded after but in connection with a treaty, established legally binding obligations. The arbitration panel concluded that such an understanding at least constituted subsequent practice of the parties and thus informed the tribunal about the correct interpretation of the treaty. ${ }^{97}$

Two instances in particular demonstrate the way that leaked information could serve as evidence of subsequent practice: the implementation of the double criminality rule in extradition and the practical application of the requirements of the Refugee Convention. Regarding the double criminality rule, the U.S. post in Bangkok has expressed concern that double criminality was being addressed by the court in the context of jurisdiction over the conduct, rather than prescription of the offense generally, ${ }^{98}$ and in the case of the Refugee

96. VCLT, supra note 15, art. 31(3)(b) (noting that subsequent practice includes "any subsequent practice in the application of the treaty which establishes the agreement of the parties regarding its interpretation"). See also VCLT Commentaries, supra note 84, art. 31 (ex-27), commentary (15) (citing Competence of the I.L.O. Extending to International Regulation of the Conditions of Persons Employed in Agriculture, Advisory Opinion, 1922 P.C.I.J., (ser. B) No. 2, 39 (Aug. 12)); Article 3, Paragraph 2, of the Treaty of Lausanne (Frontier Between Turk. \& Iraq), 1925 P.C.I.J. (ser. B) No. 12, at 24 (Nov. 21); Payment in Gold of Brazilian Federal Loans Contracted in France (Braz. v. Fr.), 1929 P.C.I.J. (ser. A) No. 21, at 119 (July 12); Corfu Channel, (U.K. /Alb.), Judgment, 1949 I.C.J. 4 (Apr. 9).

97. Accord Husserl v. Swiss Air Trans. Co., 351 F. Supp. 702,707 (S.D.N.Y. 1972) ("[A] prime cannon of treaty construction is to look to the subsequent action of the parties for the interpretation of the treaty in areas clearly unanticipated at the time."); see Heathrow Airport User Charges, Award on the First Question (U.S. v. U.K.), 34 R.I.A.A. 3, I 6.7 (Perm. Ct. Arb. 1992) ("In the judgment of the Tribunal, the MoU constitutes consensual subsequent practice of the Parties and, certainly as such, is available to the Tribunal as an aid to the interpretation of Bermuda 2 and, in particular, to clarify the meaning to be attributed to expressions used in the Treaty and to resolve any ambiguities.").

98. See DOS Cable No. 09-BANGKOK-01998, ๆף 1, 3, 11 (Aug. 13, 2009) ("The disappointing August 11 Thai Lower Court ruling against the extradition of 
Convention, the U.S. post in Moscow documented possible practice regarding resettlement coordination with the UNHCR. ${ }^{99}$

\section{d. Travaux Prépératoires}

Continuing with the examination of the Vienna Convention, the treaty provides that the rules obligatory on the parties can only be interpreted by reliance on supplementary means:

Article 32 Supplementary means of interpretation

Recourse may be had to supplementary means of interpretation, including the preparatory work of the treaty and the circumstances of its conclusion, in order to confirm the meaning resulting from the application of article 31 , or to determine the meaning when the interpretation according to article 31:

(a) leaves the meaning ambiguous or obscure; or

(b) leads to a result which is manifestly absurd or unreasonable.

Once the threshold of ambiguity is reached, the interpreter can rely

Russian arms trafficker Viktor Bout, and its dubious legal reasoning, requires a multi-pronged effort to seek a successful reversal during the appeals process. . . . His confusion of the "dual criminality" concept with jurisdictional issues similarly raises questions for efforts by Thailand to extradite fugitive former PM Thaksin to face justice. . . . Two key elements of his reasoning were: that the FARC in Colombia, to which Bout was conspiring to send weapons, was a political rather than a terrorist group; and that the "dual criminality" standard of our extradition treaty with Thailand had not been met since Bout could not be prosecuted in Thailand on the charges which the U.S. wants him to face in the U.S. In our view, the judge was wrong on both counts. Moreover, the judge's misguided analysis of the "dual criminality" standard suggests that fugitives cannot be extradited from Thailand unless a Thai court actually had jurisdiction over the alleged crime, not whether the alleged conduct is viewed as criminal conduct under the laws of both countries.").

99. See DOS Cable No. 07-MOSCOW-104, ๆף 1-3 (Jan. 12, 2007) (“"[redacted] said that [redacted] had specifically asked [redacted] whether resettlement to the United States was an option. [redacted] responded to [redacted] that the chief concern was the safety of the asylum seekers and their rapid departure from Russia, which had made South Korea the best alternative in the past, according to [redacted]. We emphasized that the U.S. was willing to accept UNHCR referrals of North Koreans and that this should be presented as an option. [redacted] agreed to do so.") (redactions in the original leaked version). 
on supplementary means such as the travaux prépératoires. ${ }^{100}$ Importantly, the VCLT does not define travaux prépératoires, and the ILC concluded that such omission was intentional. ${ }^{101}$ In fact, the ILC went so far as to acknowledge that it considered and rejected a rule that information must be published to qualify as travaux prépératoires. ${ }^{102}$ The delegates to the Vienna Conference also discussed the matter and did not act to amend the Convention to exclude secret communications. ${ }^{103}$

Leaked information might also bear on the preparatory work of a treaty. Although information that is precisely on point is sparse, WikiLeaks has published U.S. Department of State cables revealing some of the incentives that were offered at the Cancun and Copenhagen conferences on climate change. ${ }^{104}$

100. Conditions of Admission of a State to Membership in the United Nations (Art. 4 of the Charter), Advisory Opinion, 1948 I.C.J.. 57 (May 28); Interpretation of the Convention of 1919 Concerning the Employment of Women During the Night, Advisory Opinion, 1932 P.C.I.J. (ser. A/B) No. 50 (Nov. 15); VCLT Commentaries, supra note 84, art. 32 (ex-28), commentary (18) (citing Competency of the General Assembly for the Admission. of a State to the United Nations, Advisory Opinion, 1950 I.C.J. 4 (Mar. 3)).

101. See VCLT Commentaries, supra note 84, art. 32 (ex-28), commentary (20) ("The Commission did not think that anything would be gained by trying to define travaux prépératoires; indeed, to do so might only lead to the possible exclusion of relevant evidence.").

102. See id. (suggesting that publication of travaux prépératoires was unnecessary because, for multilateral treaties, parties may ask to see these documents and, for bilateral treaties, parties will already be in possession of these documents even if they are unpublished).

103. See VCLT Conference Recs., supra note 16, 32d Mtg., $\mid 18$ (as per Maliti) (claiming that because it is difficult to define what is included in the preparatory work of a treaty, "the preparatory work of the treaty and the circumstances of its conclusion could only play a secondary part in interpretation"); VCLT Conference Recs., supra note 16,33d Mtg. I 8 (as per Sinclair) (summarizing the United Kingdom's hesitancy toward utilizing preparatory works because such documents are "almost invariably confusing, unequal and partial ...").

104. See DOS Cable No. 10-STATE-18437, I 6 (Feb. 26, 2010) ("Ghafoor [Maldives Ambassador-designate] added that Maldives would like to see that small countries, like Maldives, that are at the forefront of the climate debate, receive tangible assistance from the larger economies. Other nations would then come to realize that there are advantages to be gained by compliance . . . Ghafoor referred to several projects, including harbor deepening and strengthening sea walls, that are in the development stage. These projects would cost approximately $\$ 50$ million. Pershing encouraged Ghafoor to provide concrete examples and specific costs in order to increase the likelihood of bilateral assistance and congressional 


\section{BINDing Unilateral StATEMENTS}

Turning from treaties to other sources of international law, it seems best to discuss binding unilateral statements at this point before examining customary international law, since binding unilateral statements are often very similar to treaties in form and content. In the Einhorn case, the ECHR held that diplomatic assurances could amount to binding legal obligations where they qualify as treaties. In addition, the ECHR held that, in any event, the assurances, which were communicated in secret and relied upon by France, could amount to binding unilateral statements. ${ }^{105}$ The ECHR invoked the well-known holding of the ICJ in the Nuclear Tests cases. ${ }^{106}$ This one case would be an example of how confidential

appropriations.”); DOS Cable No. 10-BRUSSELS-186 ๆ 6 (Feb. 17, 2010) ("Hedegaard [European Commissioner for Climate Action] asked if the U.S. was prepared to move forward on Fast Start funding. She said some countries like Japan and the UK will press the inclusion of loan guarantees as part of the package and asked whether the U.S. will need to do any 'creative accounting.' She added: '\$30 billion had been promised - it cannot be lent.' . . . On Fast Track financing, Pershing said the administration anticipated the need and budgeted funds in 2010 and 2011. He said some U.S. funding would be directly applied for mitigation and adaptation and other sources would be indirect, citing for example program funds from various agencies and funds for food security. He concurred that it would be valuable to agree on what funds would be included in each country's reporting, and said donors have to balance the political need to provide real financing with the practical constraints of tight budgets. He suggested that the small group of key donors-those that provide about $90 \%$ of the financing-convene quickly to discuss this issue."). The day after the aforementioned cable, Timor-Leste announced its intention to associate itself with the Copenhagen Accord and noted that it had engaged in discussions with the Maldives about its leadership on the issue. See DOS Cable No. 10-DILI-38, ๆ 2 (Feb. 18, 2010) ("President RamosHorta has made climate change a national priority and is personally engaged in diplomatic efforts to encourage other Asia-Pacific countries to group together and take a leadership role in the global negotiations. To that end, he made an official visit to the Maldives this week . . . where the agenda is expected to include discussions about climate change."). See also DOS Cable No. 10-BEIJING-349 (Feb. 10, 2010) (discussing the give-and-take of proposals and considerations between the United States and China at the Conference of Parties of the Convention on International Trade in Endangered Species).

105. See Einhorn v. France, App. No. 71555/01, 21 Eur. Ct. H.R. (2001) (maintaining that, if the diplomatic notes constituted unilateral agreements, the United States is obliged to honor its commitments).

106. See id. (citing Nuclear Tests (Austl. v. Fr.), 1974 I.C.J. 253 (Dec. 20)); see also Legal Status of Eastern Greenland (Den. v. Nor.), 1933 P.C.I.J. (ser. A/B) No. 53, at 68-69 (Apr. 5) (regarding the "Ihlen Declaration," which Norway accepted 
communications could form the basis for legal obligations.

\section{CUSTOMARY INTERNATIONAL LAW}

Customary international law is the second source of law mentioned in the ICJ Statute. The Statute of the International Court of Justice describes legal custom as "evidence of a general practice accepted as law." 107 The process by which customary international law is formed is well known, and it is widely accepted that this process produces a source of public international law. ${ }^{108}$ It entails

as binding upon itself, thereby acknowledging Danish control of Greenland). In addition, the ICJ has held that unilateral statements accepting the jurisdiction of the court are also binding. Although not precisely on point, the comparison is informative of the perspective of the ICJ. See, e.g., Mavrommatis Jerusalem Concessions (Greece v. U.K.), 1925 P.C.I.J. (ser. A) No. 5, at 37 (Mar. 26) (holding that a renunciation of the right to seize the petitioner was a legally binding statement); Rights of Minorities in Upper Silesia (Minority Schools), 1928 P.C.I.J., (ser. A) No. 12, at 23-24 (Apr. 26) (finding jurisdiction based on a statement by the respondent "in the course of the proceedings agreeing that the Court should decide a point which, in the Court's opinion, would not otherwise have come within its jurisdiction"); German Interests in Polish Upper Silesia, 1926 P.C.I.J. (ser. A) No. 7, at 13 (May 25) (affirming that a statement by the respondent promising not to requisition property was legally binding); Free Zones of Upper Savoy and the District of Gex, 1932 P.C.I.J. (ser. A/B) No. 46, at 169-70 (June 7) (ordering a declaration made by Switzerland to be binding regardless of whether France agreed to the terms).

107. See Statute of the I.C.J., supra note 6, art. 38(b).

108. See e.g., Anthony A. D'Amato, The Concept of Custom in INTERNATIONAL LAW 49, 56-66 (1971) (discussing that "evidence of a psychological element independent of the material element" is arguably not required to prove the existence of opinio juris); Final Report of the Committee on the Formation of Customary (General) International Law, Statement of Principles Applicable to the Formation of General Customary International Law, 69 INT'L L. ASS'N REP. CONF. 713, 719-20 (2000) [hereinafter ILA REPORT] (concluding that if enough states engage in regular behavior that behavior will develop into a customary international law); $\mathrm{H}$. LAUTERPACHT, THE DEVELOPMENT OF INTERNATIONAL LAW BY THE INTERNATIONAL COURT 368-93 (1958) (analyzing the "psychological conception" of opinio juris in detail); Maurice H. Mendelson, The Formation of Customary International Law, in 272 ACADEMIE DE DROIT InTERNATIONAL 155-59 (Recueil des Cours, 1999); Luigi Condorelli, Custom, in InTERNATIONAl LAW: ACHIEVEMENTS AND PerspeCtives 206 (M. Bedjaoui ed., 1991) (arguing that a State that relies on a regional or local custom must first prove the existence of such a custom); Bin Cheng, Custom: The Future of General State Practice in a Divided World, in THE Structure AND PROCESS Of INTERNATIONAL LaW: EsSAys IN Legal Philosophy Doctrine AND Theory 513, 533-34 (R. St. J. Macdonald \& D. Johnston eds., 1983) (positing that the legal framework of 
two elements: (1) state practice, the objective or material element, and (2) opinio juris, the subjective or psychological element. ${ }^{109}$

The particular items that can serve as evidence for the formation of customary international law form a laundry list. As per the ILC, such a list includes texts of international instruments, decisions of international courts, decisions of national courts, national legislation, diplomatic correspondence, opinions of national legal advisers, and practice of international organizations. ${ }^{110}$ In addition to ILC's possible evidentiary sources, Brownlie offers a partly overlapping and partly supplementary statement of evidence of customary international law, including diplomatic correspondence, policy statements, press releases, opinions of legal advisers, official manuals on legal questions, comments by governments on drafts by the ILC, state legislation, international and national judicial decisions, recitals in treaties and other international instruments, pattern of treaties in the same form, practice of international organs,

customary law is unlike the law of treaties, which is "relatively well known").

109. See Nicaragua Judgment, supra note 8, at 108 ("[B]efore reaching a conclusion on the nature of prohibited intervention, the Court must be satisfied that State practice justifies it."); Continental Shelf (Tunis./Libyan Arab Jamahiriya), 1982 I.C.J. 18, 42 (Feb. 24) (inferring that a customary law could develop in a short time if adherence to a practice included "specially affected" states); Right of Passage over Indian Territory (Port. v. India), 1960 I.C.J. 6, 44 (Apr. 12) ("Where therefore the Court finds a practice clearly established between two States which was accepted by the Parties as governing the relations between them, the Court must attribute decisive effect to that practice for the purpose of determining their specific rights and obligations."); Asylum (Colom./Peru), 1950 I.C.J. 266, 276 (Nov. 20) (requiring Colombia to prove the "constant and uniform usage" of the State practice that they wish to invoke as customary international law); S.S. "Lotus" (Fr. v. Turk.) 1927 P.C.I.J. (ser. A) No. 10, $27-28$ (1928) (declining to find a State practice of accepting jurisdiction in collision cases in the State "whose flag is flown" on the ship); MALCOLM N. SHAW, INTERNATIONAL LAW 75 (6th ed. 2008) (explaining that psychological elements require a State to act in accordance with State practice because it believes it is legally obligated to do so); IAN Brownlie, Principles of Public International LaW 4-11 (5th ed. 1998) (outlining the elements of customary international law, including duration, consistency of practice, generality of practice, and acting in accordance with a perceived legal obligation).

110. See generally Ways and Means for Making the Evidence of Customary International Law More Readily Available, supra note 81 (discussing all the types of documents that can serve as evidence for the formation of customary international law). 
and resolutions relating to legal questions in the UNGA. ${ }^{111}$ The International Committee of the Red Cross ("ICRC") also identified the types of documents it would examine in seeking to discern the rules of customary international humanitarian law, with considerable overlap with the above. In particular, the ICRC examined statements made in the context of international organizations, national legislation, parliamentary debates, and military operational manuals. ${ }^{112}$

Of these various sources of evidence, the ones relevant for leaked information-i.e., the ones likely to have been confidential-are diplomatic correspondence, the opinions of national legal advisers, and official manuals on legal questions. In light of the official manual Rules of Engagement in Iraq, which was posted on WikiLeaks, the last source is particularly significant. ${ }^{113}$

One way in which leaked information might have bearing on the rules is the identification of specially affected states. When assessing state practice and opinio juris, scholars and courts will usually decline to examine every state in the world and will instead identify certain representative states, "specially affected states," as a shorthand way to find relevant evidence. ${ }^{114}$ Leaked information

111. BROWNLIE, supra note 109 , at 6 .

112. See, e.g., InT'L COMM. RED CRoss, Customary InTERnATIOnAL Humanitarian Law Vol. I: Rules xxiv, xl (Jean-Marie Henckaerts \& Louise Doswald-Beck, eds., 2005) [hereinafter ICRC CUSTOMARY IHL STUDY] (confirming that such documents establish the existence of a State practice that "riot-control agents must not be used in hostilities"). For an example of the application of these sources, see $i d$. at 264, Rule 75; see also Prosecutor v. Tadić, Case No. IT-94-1-AR72, ๆ 99 (Int'l Crim. Trib. for the Former Yugoslavia, Oct. 2, 1995) (concluding that to demonstrate a customary rule a State must produce evidence, such as a military operational manual, because it is otherwise implausible "to pinpoint the actual behavior of the troops in the field for the purpose of establishing they in fact comply with, or disregard, certain standards of behavior").

113. US Rules of Engagement for Iraq, WIKILEAKS, Apr. 5, 2010, http://file.wikileaks.org/file/rules of engagement.pdf.

114. See Continental Shelf, 1982 I.C.J. at 70, ๆ 93-95; North Sea Continental Shelf (Germ./Den.; Germ./Neth.), 1969 I.C.J.. 3, 227 (Feb. 20) ("Again, it is noteworthy that while 39 States are parties, initial steps towards the acceptance of the Convention have been taken by 46 States, who have signed it: half of them have ratified it . . This mathematical computation, important as it is in itself, should be supplemented by, so to speak, a spectral analysis of the representativity of the States parties to the Convention.”); Corfu Channel, (U.K. /Alb.), 1949 I.C.J. 
might provide context for the acts of states and perhaps justify identification of certain states as specially affected.

However some of this information might be originally secret. We have already dismissed questions of ex turpi and fruit of the poisonous tree arguments, so we need only examine whether there is any rule of international law that would prohibit secretly made statements that were subsequently leaked from being considered in the assessment of state practice and opinio juris.

In its study of customary international law, the International Law Association concluded that practice must be public to qualify as such for purposes of the formation of customary international law. ${ }^{115}$ The ICRC echoed this conclusion and cited to the ILA. ${ }^{116}$ Tullio Treves writing in the Max Planck Encyclopedia argues similarly. ${ }^{117}$ Unfortunately, the ILA and others do not cite to any authority for

4 (Apr. 9); S.S. "Wimbledon" (U.K./Japan), 1923 P.C.I.J. (ser. A) No. 1, at 25 (Aug. 17) (relying on the Suez and Panama Canal Treaties alone to demonstrate a custom of the neutrality of international canals); Special Tribunal for Lebanon, Case No. STL-11-01/I, Interloc. Dec. on the Appl. Law, 87 (App. Chambers, Feb., 16, 2011) (" $[T]$ he distillation of a shared norm does not require a comprehensive survey of all legal systems of the world.") (citing Prosecutor v. Erdemović, Case No. IT96-22-A, Judgment, 91 (Int'l Crim. Trib. for the Former Yugoslavia, 1997) (McDonald \& Vohrah, Js.) ("It is generally accepted that [a] comprehensive survey of all legal systems of the world [is not required] as this would involve a practical impossibility and has never been the practice of the International Court of Justice or other international tribunals which have had recourse to Article 38(1)(c) of the ICJ Statute." Note, however, that the ICTY was discussing general principles of law, not customary international law.)); ILA REPORT, supra note 108, Principle 14, commentary (e); ICRC CUSTOMARY IHL STUDY, supra note 112, at xliv ("One reason why it is impossible to put a precise figure on the extent of participation required is that the criterion is in a sense qualitative rather than quantitative. That is to say, it is not simply a question of how many States participate in the practice, but also which States.").

115. See ILA REPORT, supra note 108, Principle 5 (setting forth that an act must either be published or at least communicated to one other State to be considered public).

116. See ICRC CUSTOMARY IHL StUdy, supra note 112, at $\mathrm{xl}$ (adding that actions cannot be public if other States do not have the chance to respond to the actions).

117. See Tullio Treves, Customary International Law, in MAX PLANCK ENCYCLOPEDIA OF PUBLIC INTERNATIONAL LAW ๆ 79 (2006) available at http://www.mpepil.com/sample_article?id=/epil/entries/law-9780199231690e1393\&recno=34\& (explaining that "unpublished practice" is not helpful in shaping customary international law for the simple fact that the majority of States are not aware of its existence). 
support of this conclusion other than the logic of customary international law, when we assume it is based on an "offer acceptance" model. Of course, it is not entirely clear in international law that such an explanatory model necessarily has a normative effect on the formation of customary international law. As an example of evidence that would not qualify as evidencing customary international law, the ILA stated, "Internal memoranda are therefore not, as such, forms of State practice, and the confidential opinions of Government legal advisers, for instance, are not examples of the objective element in custom." "118 This example cannot be right. An internal memorandum is not practice, other than the practice of writing a memorandum. The memorandum can only document a practice or evidence an opinio juris. However, just because the practice or opinio juris is documented in an internal memorandum does not mean that it was not "public" in the sense used by the ILA. A highly visible, public act that was described in a confidential memorandum that was subsequently leaked should be admissible as evidence of the public practice. The ILA and ICRC reason that, to be a state practice for purposes of customary international law, other states must have an opportunity to react to the practice as lawful or unlawful. ${ }^{119}$ The ICJ has relied on internal memoranda for proof of facts. ${ }^{120}$ Therefore, the "public" aspect should be understood to be "public" in the sense that it need not "necessarily be communicated to all of the world, but that, if it is not publicized generally (e.g. by

118. ILA REPORT, supra note 108, Principle 5, commentary a.

119. Id. (")(a) . . If the customary process is seen as one of claim and response, the reason is clear: an internal memorandum which is not communicated to others is not a claim or a response. (It is otherwise if the State publicizes the legal analysis in support of its position: it then becomes part of its claim.) If the memorandum is only afterwards made public (e.g. through the operation of laws opening national archives to the public after a certain period of time), it may be evidence of the State's subjective attitude to the issue, but is not an instance of the 'objective element'. (b) By the same token, a secret physical act (e.g. secretly 'bugging' diplomatic premises) is probably not an example of the objective element. And if the act is discovered, it probably does not count as State practice unless the State tries to assert that its conduct was legally justified."); see also ICRC CUSTOMARY IHL STUDY, supra note 112, at xl ("This is so as long as such acts are not known to other States and, consequently, do not give them an opportunity, if they so wished, to react to them. In order to count, practice has to be public or communicated to some extent.").

120. See Nicaragua Judgment, supra note 8, ๆ 136 (relying on an internal memo, supplied by Nicaragua, to show that Nicaragua supplied arms to El Salvador). 
legislation, press statements, etc.), it must be communicated to at least one other State." 121 The ICRC reasons similarly that the acts must be communicated, but it would also permit communication to the ICRC to count. ${ }^{122}$ There is no justifiable reason for distinguishing between information made public through official or inadvertent release and leaked, other than the usual concerns about reliability that would be applied to any evidentiary matter. Leaked information is often the report of information that has been communicated from state to state, or, where it was not communicated, states have had the opportunity to react after the leak. Therefore, leaked acts should qualify as public. In any event, once leaked, the information becomes public, and states have ample opportunity to complain.

For similar reasons, secret or internal communications brainstorming about possible courses of action should not be inadmissible as evidence of opinio juris simply because they are, or were, confidential. Indeed, the fact that they were made in an internal context might diminish their evidentiary value, but their nature as secret should not render them inadmissible per se on the basis of not contributing to the formation of customary international law. In fact, the ICJ has ruled that an official, although originally secret, communication about an undertaking between executives would evidence the opinio juris regarding the obligation. ${ }^{123}$

There does not seem to be a rule prohibiting leaked documents from being used for evidentiary purposes in proving a rule of customary international law, and, in fact, it appears that international law (or at least international actors) encourage their use. In the Nicaragua case, the ICJ opined that statements by "high-ranking official political figures, sometimes indeed of the highest rank, are of particular probative value when they acknowledge facts or conduct unfavourable to the State represented by the person who made

121. ILA REPORT, supra note 108, Principle 5, commentary (a); Treves, supra note $117, \mathbb{\top} 79$.

122. See ICRC CUSTOMARY IHL StUdy, supra note 112, at xl (conveying that publication to the ICRC is adequate because "communications to the ICRC, while often confidential, are not purely private acts and count as State practice").

123. See Armed Activities on the Territory of the Congo, (Dem. Rep. Congo v. Rwanda), 2006 I.C.J. 27, 9 46-47 (affirming that the executive branch is the primary branch to formulate international obligations). 
them." ${ }^{24}$ This statement could be implicitly condoning the use of leaked information, since unfavorable admissions might be more likely in confidential communications. In addition, when the ILC examined the "Ways and Means for Making the Evidence of Customary International Law More Readily Available," the Commission expressed a frustration that this kind of valuable information was not usually published. ${ }^{125}$ In discussing diplomatic correspondence, the ILC argued that limiting access to such correspondence was detrimental to the cause of discovering customary international law. ${ }^{126}$ In discussing the opinions of national legal advisers, the ILC similarly expressed concern at the lack of publication or dissemination of those materials. ${ }^{127}$ Even the very working title of "Ways and Means for Making the Evidence of Customary International Law More Readily Available" suggests that the ILC thought it was a legitimate goal to encourage increased access to helpful materials, although the ILC's primary concern might have been inability to publicize rather than intent to maintain secrecy.

There are a number of instances where leaked documents might be considered in the context above as evidence of state practice or opinio juris. Several leaked cables show that the leaders of Saudi Arabia, ${ }^{128}$ Abu Dhabi, ${ }^{129}$ and other Arab states ${ }^{130}$ urged the United

124. Nicaragua Judgment, supra note 8, at 41.

125. See Ways and Means for Making the Evidence of Customary International Law More Readily Available, supra note 81, at 368-72, I 87 (advocating that to remedy this problem, States should publish digests, sponsored by the government, detailing their international practice).

126. See id. 971 ("The diplomatic correspondence between Governments must supply abundant evidence of customary international law. For various reasons, however, much of the correspondence is not published. Within the limits set by propriety, some Governments publish selected texts of diplomatic exchanges, but frequently only after a lapse of years. Archives of foreign offices are in some cases opened to access by qualified scholars engaged in research, but usually only up to a particular time.").

127. See id. 976 ("The opinions on questions of international law given by legal advisers to Governments are published in few countries.").

128. See DOS Cable No. 10-RIYADH-184, supra note 29, ๆ 10 ("Al-Jubeir recalled the King's frequent exhortations to the US to attack Iran and so put an end to its nuclear weapons program. 'He told you to cut off the head of the snake,' he recalled to the Chargé, adding that working with the US to roll back Iranian influence in Iraq is a strategic priority for the King and his government.").

129. See DOS Cable No. 07-ABU DHABI-187 (Feb. 7, 2007) (discussing the 
States to attack Iran. The officials were clearly aware of international law generally - the Foreign Minister of Saudi Arabia and one of the princes did mention it $^{131}$ — but they did not mention that such an action might be unlawful. The cables also substantiate the claims that the United States has used force in Yemen, potentially unlawfully. ${ }^{132}$ Both of these cases might show an evolution in customary international law on the use of force. In addition to the use-of-force cases, the leaked cables have also shown that the U.S. Secretary of State routinely ordered U.S. officials to collect "intelligence" on U.N. officials, including orders to collect credit card information, passwords, and frequent-flyer account numbers. These included U.N. officials as high-ranked as the U.N. Secretary General, who is supposed to be inviolable. ${ }^{133}$ One report discusses the Argentine practice regarding the law of the sea as of 1966, being six-mile territorial waters, six-mile exclusive fishing, and 200-mile extended preferential jurisdiction. ${ }^{134}$ Other cables have reported on offers for transfer of Guantanamo detainees to Slovenia and Belgium, apparently in exchange for increased diplomatic access and prominence in Europe, ${ }^{135}$ and a warning by the United States to

growing threat of Iran and positing that Iran's nuclear program must be stopped).

130. But see DOS Cable No. 07-DUBAI-355 (June 3, 2007) (reporting that Sheikh Mohammed bin Rashid Al Maftoum of Dubai, when meeting with Joseph Lieberman, urged the United States not to use force against Iran).

131. See DOS Cable No. 10-RIYADH-184, supra note 29, ๆ 11 (discussing the possibility that tougher sanctions against Iran could be implemented without prior U.N. approval).

132. See DOS Cable No. 09-SANAA-2251, ๆ 5 (Dec. 21, 2009) ("Given that local and international media will continue to look for evidence of a U.S. role in the December 17 strikes against AQAP [Al-Qaeda in the Arabian Peninsula], the ROYG [Republic of Yemen Government] must think seriously about its public posture and whether its strict adherence to assertions that the strikes were unilateral will undermine public support for legitimate and urgently needed CT operations, should evidence to the contrary surface. Thus far, the ROYG has deployed influential local leaders to the affected area in Abyan to explain the need for the strikes in an effort to quell potential unrest; however, it has not attempted to provide any context for the civilian casualties, which might help to counter overblown claims of ROYG disregard for the local population ) [sic] in this particular case, southerners."). See also DOS Cable No. 10-RIYADH-184, supra note 29, 4 (expressing Saudi support for U.S. strikes in Yemen).

133. See DOS Cable No. 09-STATE-80163 (July 31, 2009) (discussing the "HUMINT" directive).

134. See DOS Cable No. 66-BUENOS AIRES-2481 (Dec. 28, 1966).

135. See DOS Cable No. 09-BRUSSELS-1580, ๆ 5 (Nov. 24, 2009) ("The 
Germany not to prosecute CIA officers in a botched arrest operation.

\section{E. ACTS OF INTERNATIONAL ORGANIZATIONS}

The degree to which international organizations can make law is controversial, but leaked documents might give us some insight into the effects of international organization acts in the internal policies and choices of governments. An example of this effect is the report on the Serbian government's internal consideration of the orders from the ICTY. ${ }^{136}$ The way in which states receive, process, and

Embassy has been encouraging Belgium to take a leadership role in Europe in the closure of the Guantanamo detention center. In October, Belgium resettled one detainee, whose successful integration should be reassuring to Belgian officials. We are discussing the transfer of two Tunisian detainees who have already been convicted of crimes in Belgium, not as part of the 'placement' of detainees, but instead as part of our Department of Justice working with the Belgian Ministry of Justice (our hope is that that process will make it easier for Belgian society to accept the return, and also allow us to ask the Ministry of Foreign Affairs separately to take others). We have also begun to suggest the possibility of Belgium stepping forward from the chorus line and up to the footlights on Guantanamo. Helping solve the USG's - and Europe's - problem with Guantanamo is a low-cost way for Belgium to attain prominence in Europe. There are signs that Belgium's reticence is beginning to chafe its leadership. Complaints about Belgium's exclusion from G-20 membership, and opposition to perceived influence of a 'directoire' of large countries in the EU are examples. It is a matter of convincing Belgium that not only does it have self-interest in a more assertive role, but it also has a uniquely trusted character within Europe that permits it to be effective. Embassy Brussels suggests the time is right to ask Belgium to take more than a handful of detainees and ask in coordination with others (as led by Belgium), so that Guantanamo - which Europeans always so roundly condemned - is closed once and for all.").

136. See DOS Cable No. 06-BELGRADE-1681, qศ 1-2 (Oct. 17, 2006) ("Carla del Ponte has sharply criticized the ineffectiveness of GoS [Government of Serbia] implementation of the 'Action Plan' Serbia negotiated this summer with ICTY and has told us that the PM has demonstrated no political will to take the steps necessary to bring about Mladic's arrest. By contrast, the PM declared over the weekend that Serbia has done 'absolutely everything' to cooperate with ICTY and criticized the EU's 'irrational' approach on Hague conditionality."); see also DOS Cable No. 09-BELGRADE-399, ๆ 1 (May 6, 2009) ("The Serbian government continues to publicly emphasize its efforts to capture war crimes indictee Ratko Mladic, and Serbian officials responsible for cooperation with the International Criminal Tribunal for the Former Yugoslavia (ICTY) privately tell us the current government is very supportive of their work. ICTY Belgrade's chief, who sits in on operations discussions, agreed that Serbia was looking hard for Mladic and was also providing all document and witness assistance required, in contrast to the previous government's efforts. Serbia also continued to prosecute domestic war 
consider the acts of international organizations in the formation of their policy choices evidences an opinio juris regarding the legal value of those acts, perhaps going so far as to amend the provisions on legal value contained in the constitutive instrument of the organization.

\section{INTERNATIONAL LEGAL PERSONALITY}

We might also consider the effect of leaked documents on the legal personality of certain entities. This article is primarily concerned with the formation of law, not facts. However, the formation of law is often dependent on the establishment of facts, and the legal personality of an entity is usually considered to be a mixed question of law and fact. ${ }^{137}$ Furthermore, whether an entity is an international legal person has bearing on whether that entity can contribute to the formation of international law and is thus also important for law in that way.

The Holy See and Kosovo are two entities with less than universal recognition of personality that have been the subject of discussion in leaked documents. ${ }^{138}$ Recently, Geoffrey Robertson has questioned the statehood, or international legal personality, of the Vatican and/or Holy See, and thus the derivative Head of State immunity of the Pope. ${ }^{139}$ Leaked documents may evidence a crack in the edifice of the personality of the Holy See/Vatican. In the midst of the sexual abuse scandals in Ireland, a nation that might be expected to be one of the

crimes cases, and the war crimes court recently issued verdicts and sentences in two high-profile cases. The current government clearly wants to find Mladic, a prerequisite for moving ahead with EU accession and Serbia's future.").

137. Cf. Michael Byers, Custom, Power, and the Power of Rules: Customary International Law from an Interdisciplinary Perspective, 17 MICH. J. INT'L L. 109, 156 (1995) (asserting that recognition is an important question in determining whether an entity has legal personality).

138. These are not the only examples. See, e.g., DOS Cable No. 10JERUSALEM-292 (Feb. 17, 2010) (discussing upcoming Palestinian municipal elections but using expressions like "national" elections, "PA [Palestinian Authority] President," and Palestinian "law," which could suggest an evolving position on Palestinian statehood); DOS Cable 10-AI TAIPEI-157 (Feb. 10, 2010) (examining Taiwan-P.R. China cross-straits trade discussions for similar occasional terminology, suggesting a less than absolute position on Taiwan).

139. See generally GeOfFrey Robertson, THE CASE of THE Pope: VATICAN ACCOUNTABILITY FOR HuMAN RightS ABUSE (2010). 
more adamant defenders of the personality of the Holy See, the Murphy Commission, a non-judicial organ, directly ordered the Papal Nuncio to testify and did not send such an order through diplomatic channels. ${ }^{140}$ The Nuncio responded that a foreign ambassador cannot be compelled to testify. ${ }^{141}$ The Irish government later intervened to halt the request, but the immunity flowing from international legal personality was not widely perceived or accepted. ${ }^{142}$ However, the recent closure of the Irish mission to the Holy See, the complaint to the ICC against the Pope and others, and the recent decision of the Queen's Bench that priests of the Roman Catholic Church can be assimilated to employees of a corporation for vicarious liability purposes may evidence a waning of the perception of international legal personality in the Holy See and/or Vatican City. ${ }^{143}$

140. Frances D'Emilio, Irish Angry at Vatican as Summit Ends, GUARDIAN (Feb. 16, 2010), http://www.guardian.co.uk/world/feedarticle/8947353/print.

141. Brian Lavery, Church to Pay $\$ 323,000$ and Apologize in Irish Sex Abuse Case, N.Y. TIMES (Apr. 10, 2003), http://www.nytimes.com/2003/04/10/world/ church-to-pay-323000-and-apologize-in-irish-sex-abuse-case.html.

142. See DOS Cable No. 10-VATICAN-33, I 5 (Feb. 26, 2010) ("The Irish government wanted to be seen as cooperating with the investigation because its Education Department was implicated, but did not want to insist that the Vatican answer the requests because they had come outside of regular channels. In the end, the Irish government decided not to press the Vatican to reply, according to Fahey's Deputy, Helena Keleher. Moreover, Keleher told Polchief the CDF [Congregation for the Doctrine of the Faith] probably did not have much to add to the inquiry. Regarding the request for the Nuncio to testify, Keleher said the GOI [Government of Ireland] understood that foreign ambassadors are not required or expected to appear before national commissions. Nevertheless, Keleher thought the Nuncio in Ireland made things worse by simply ignoring the requests."). But see DOS Cable No. 01-VATICAN-3507 (July 3, 2001) (maintaining confidentially the United States' position that the Vatican enjoys international legal personality, although that is not necessarily the same thing as statehood).

143. See J.G.E. v. English Province of Our Lady of Charity, [2011] EWHC (Q.B.) 2871 (Eng.) (MacDuff, J.); Philip Pullella, Vatican Stunned by Irish Embassy Closure, REUTERS, Nov. 4, 2011, http://www.reuters.com/article/2011/ 11/04/us-vatican-ireland-idUSTRE7A33D120111104 (observing that Ireland explained the decision to close its embassy as a financial austerity measure to meet EU-IMF bailout expenditure requirements); CTR. FOR CONSTITUTIONAL RIGHTS, Victims' Communication Pursuant to Article 15 of the Rome Statute Requesting Investigation and Prosecution of High-level Vatican Officials for Rape and Other Forms of Sexual Violence as Crimes Against Humanity and Torture as a Crime Against Humanity, ICC File No. OTP-CR-159/11 (Sept. 13, 2011), available at http://s3.documentcloud.org/documents/243877/victims-communication.pdf. 
Kosovo is a second case. Kosovo is not universally regarded as a state, ${ }^{144}$ and the leadership of Serbia has been publically adamantly opposed to it operating as or becoming an independent state. This opposition by Serbia in turn might be a cause for Russian opposition, and hence a potential veto for U.N. membership. Leaked cables report a slightly different story. In one of the cables, Ambassador Mary Warlick reported about her February 3, 2010, conversation with President Boris Tadić's foreign policy adviser Jovan Ratkovic. Ambassador Warlick wrote that Ratkovic "detailed his plans to discuss possible ways forward on Kosovo," that would include "discreet brainstorming" with U.S. State Department officials and members of Congress, saying that Serbia sought a "realistic, pragmatic, peaceful, win-win solution for Serbs and Albanians." This brainstorm included a variety of scenarios:

Kosovo; Option B: Partition; Option C: Serbia chooses between Kosovo or the EU. Option A (i.e., finding a way to define Serbia's special interests in the north and with the status of some churches in the south) most likely reflects the ideas that Belgrade is most interested in exploring. While Serbia's lack of a commitment to recognize Kosovo will remain an EU stumbling in the long-term, Ratkovic's overture next week may provide an initial first step toward defining a more realistic modus vivendi, which we have been encouraging the Serbs to explore. ${ }^{145}$

144. See International Recognition of Kosovo, WIKIPEDIA, http://en.wikipedia.org/wiki/International_recognition_of_Kosovo (last visited Oct. 9, 2012). Whether Wikipedia, as opposed to WikiLeaks, constitutes a reliable enough source for academic research purposes is an entirely different question.

145. DOS Cable No. 10-BELGRADE-25 (Feb. 5, 2010) ब15; see also DOS Cable No. 06-BELGRADE-1681, supra note 136, ๆ 1 ("We expect Serbia will continue to obstruct and undermine Kosovo's sovereignty in the lead up to and following the International Court of Justice's advisory opinion, which most believe will be ambiguous. Regardless of the position taken by the ICJ, Kosovo's independence and sovereignty are irrefutable. Serbia's government is unified in its refusal to accept that fact but is internally divided regarding how to push its claim to Kosovo after the ICJ issues its opinion in spring 2010. President Boris Tadic and his office appear willing to follow our and the EU's advice and to quietly accept any outcome while moving Serbia toward EU integration, but are lacking a coordinated plan to do so. In contrast, Foreign Minister Vuk Jeremic, driven by personal interest in self promotion [sic] and a misperception of the domestic political landscape, is planning a new diplomatic offensive on Kosovo on the heels of any ICJ opinion. Absent an alternative approach by Tadic, we expect Jeremic's more confrontational plan will win out. To temper Serbia's post ICJ strategy and to limit its duration and impact, we will need to be well coordinated with our EU 
This discussion suggests a far less entrenched opposition, as was apparently evidenced most recently in the new approach to permitting Kosovo international participation, ${ }^{146}$ which could mean that the real blend of law and fact tilts in favor of Kosovar statehood.

\section{LEX FERENDA}

Lastly, this article would be remiss in failing to mention that leaked information can have a slightly different and additional impact on the rules of international law through lex ferenda. Knowledge of secret interactions, deals and practices can inspire and motivate change of the lex lata. Perhaps the rules on responsibility should be changed in light of the intense level of involvement certain corporations have been revealed to have in some governments. ${ }^{147}$ This author will not go so far as others who might argue that public

allies and encourage the EU to wisely use its significant remaining carrots and sticks with Serbia to elicit the cooperative resolution of this issue, while assuring Kosovo's territorial integrity. We must also be prepared to fight Serbia in the UNGA if necessary."); DOS Cable No. 09-PRISTINA-77, ๆ 7 (Feb. 23, 2009) ("If Kosovo is to succeed as a long-term proposition - and it most certainly can our sustained engagement is necessary to bolster European resolve, bring Belgrade to a more realistic sense of its equities in peace and stability, and take a firm line with the UN on further reducing its presence in Kosovo. These meetings in Washington will help reinforce the sense that Kosovo is moving forward and imbue Kosovo's leadership with a renewed sense of confidence as they prepare to face the many challenges ahead.").

146. See Matthew Brunwasser, Kosovo and Serbia Reach Key Deal, N.Y. TIMES, Feb. 24, 2012, http://www.nytimes.com/2012/02/25/world/europe/25ihtkosovo25.html? scp=2\&sq=Kosovo\&st=cse (explaining that, in exchange for allowing Kosovars to represent themselves in "international forums," Kosovo's name will not include the word "Republic").

147. See DOS Cable No. 06-THE HAGUE-2654 (Dec. 21, 2006) (noting Dutch support of targeted sanctions against Iran as long as they do not harm Shell operations); DOS Cable No. 07-THE HAGUE-246 (July 9, 2007) (discussions between the US Ambassador, the Dutch Government, and Shell regarding its operations in Iran); DOS Cable No. 07-THE HAGUE-935 (May 16, 2007) (reporting that Shell regularly briefs the Dutch government on its activities in Iran; also stating that Shell has its employees in all Nigerian government ministries and knows "everything that was being done in those ministries"). See also DOS Cable No. 09-MADRID-71, ๆ 9 (Jan. 21, 2009) (describing the degree to which the U.S. government was involved in advocating for a Spanish Ministry of Defense contract bid by General Electric against a competing bid by Rolls-Royce, and the personal involvement of Zapatero in overruling the final award of the bid to Rolls-Royce in favor of GE because it was "important to the USG [U.S. government]"). 
opinion in itself can change the rules; however, public opinion can motivate change in behavior by the actors and result in changes in the law.

\section{CONCLUSION}

This article has attempted to suggest some possibilities for the impact that secret, but leaked, information could have on the rules of international law. To determine what the effect might be, we looked at the various sources of law enumerated in the ICJ Statute, as well as binding unilateral statements and the acts of international organizations.

As threshold matters, ex turpi causa non oritur actio, the fruit of the poisonous tree, and similar principles were examined since the leaking and/or acquiring of leaked information might be criminal. $E x$ turpi and related principles were dismissed for a number of reasons: (1) there was no clear reliance on the wrong itself but rather the facts in a document that was not itself wrongful; (2) the actors that sought to rely on the information were not the ones committing the wrong; (3) the crime committed, if any, would be one of domestic law, not of international law; and (4) any wrong committed is not of sufficient gravity to counterbalance ex factis jus oritur. Fruit of the poisonous tree was also dismissed for the following reasons: (1) it is uncertain whether the rule even exists in international law in the context of state responsibility, not international individual criminal responsibility, and (2) even if the rule does exist in some way in international law, it was questioned whether exclusion is a remedy under international law in state-to-state relationships.

This paper then proceeded to examine the law of treaties for two purposes. First it assessed the definition of a treaty, and second it assessed the evidentiary function in interpreting treaties. As for the first possibility, there did not appear to be any difficulty with a leaked document, even one conceived and adopted in secrecy, being a treaty itself. This analysis also necessitated a brief examination of the non-legally binding agreement and whether such an agreement could constitute a treaty notwithstanding its non-legally binding nature. Leaked information might shed light on the intended legal effects of these kinds of documents. Turning to the second possibility under the law of treaties, we examined the ways in which leaked 
information might serve an evidentiary function in interpreting treaties, by giving us insight into the ordinary meaning, context, and object and purpose of a treaty; documenting travaux prépératoires; or evidencing subsequent agreement or practice between the parties.

This paper also considered the ways in which leaked information might contribute to the formation of customary international law, primarily the ways in which leaked information might evidence practice and opinio juris. Several important evidentiary roles were identified, most importantly documenting the practice and opinio juris themselves, but also, for example, assisting in identifying specially interested or specially affected states. Although some authorities have objected to the use of secret documents as evidence of custom, this author concluded that it is not the secret nature of the documenting of practice that is problematic, but rather the secret nature of the practice itself. Thus, the form and manner of documenting practice does not affect its evidentiary value. In any event, once a secret document is leaked, it ceases to be secret and the question is moot.

Lastly, the author also considered the potential for leaked information to contain binding unilateral statements and the role that leaked information might play in the law-making function of international organizations.

Having concluded on the sources of law, this paper took a brief detour to examine the ways in which leaked information might affect the international legal personality some entities enjoy. Generally, this question is regarded as a mixed one of fact and law. Leaked information might have a bearing on both the law to be applied and the facts to be established. In particular, the Holy See and Kosovo were discussed in leaks.

Although WikiLeaks and the phenomena that it represents have raised many questions in the law, to date we have not been discussing the question of the effect that leaked information might have on the law. To a large degree, leaked information does not have a significant impact beyond functioning within the normal doctrine on the sources of law. We appear to be moving into an era of increased access and transparency, and inability to prevent the viral spread of leaked information. Law, and international law in particular, must take cognizance of this change and absorb it. It is 
possible through the normal rules for now, although the growth in leaked information might have a greater effect in the future. It might even inspire changes in some of the more fundamental notions that underpin the law. 